\title{
Congenital Cytomegalovirus Infection Alters Olfaction Before Hearing Deterioration In Mice
}

\author{
(1)Françoise Lazarini, ${ }^{1,2}$ Lida Katsimpardi, ${ }^{1,2 \star}$ Sarah Levivien, ${ }^{1,2,3 \star}$ Sébastien Wagner, ${ }^{1,2}$ (P) Pierre Gressens, ${ }^{3,4,5}$ \\ Natacha Teissier, ${ }^{3,4,6 \dagger}$ and Pierre-Marie Lledo ${ }^{1,2}{ }^{\dagger}$ \\ ${ }^{1}$ Institut Pasteur, Perception and Memory Unit, F-75015 Paris, France, ${ }^{2}$ Centre National de la Recherche Scientifique, Unité Mixte de Recherche 3571, \\ F-75015 Paris, France, ${ }^{3}$ PROTECT, INSERM, Unité 1141, F-75019 Paris, France, ${ }^{4}$ Paris Diderot University, Sorbonne Paris Cité, F-75018 Paris, France, \\ ${ }^{5}$ Center for Developing Brain, King's College, London, WC2R2LS United Kingdom, and ${ }^{6}$ Pediatric Otorhinolaryngology Department, Robert Debré Hospital, \\ Assistance Publique-Hôpitaux de Paris, F-75019 Paris, France
}

In developed countries, cytomegalovirus (CMV)-infected newborns are at high risk of developing sensorineural handicaps such as hearing loss, requiring extensive follow-up. However, early prognostic tools for auditory damage in children are not yet available. In the fetus, CMV infection leads to early olfactory bulb (OB) damage, suggesting that olfaction might represent a valuable prognosis for neurological outcome of this viral infection. Here, we demonstrate that in utero CMV inoculation causes fetal infection and growth retardation in mice of both sexes. It disrupts $\mathrm{OB}$ normal development, leading to disproportionate $\mathrm{OB}$ cell layers and rapid major olfactory deficits. Olfaction is impaired as early as day 6 after birth in both sexes, long before the emergence of auditory deficits. Olfactometry in males reveals a long-lasting alteration in olfactory perception and discrimination, particularly in binary mixtures of monomolecular odorants. Although sensory inputs to the $\mathrm{OB}$ remain unchanged, hallmarks of autophagy are increased in the OB of 3-postnatal week-old mice, leading to local neuroinflammation and loss of neurons expressing tyrosine hydroxylase and calbindin. At the cellular level, we found CMV-infected cells and an increased number of apoptotic cells scattered throughout the OB layers, whereas cell proliferation in the neurogenic subventricular zone was decreased. These cellular observations were long-lasting, persisting up to 16 weeks after birth in both males and females and thus providing a mechanism supporting olfactory loss. Despite obvious differences in neurogenesis between human and mouse, these findings offer new strategies aimed at early detection of neurological dysfunctions caused by congenital infections.

Key words: congenital; cytomegalovirus; deafness; hyposmia; interneuron; olfactory bulb

Significance Statement

In developed countries, congenital cytomegalovirus (CMV)-infected newborns are at high risk of developing sensory handicaps such as hearing loss, thus requiring prolonged follow-up. In this study, we describe for the first time the functional impact of congenital CMV infection on the olfactory system and its associated sense of smell. We demonstrate that a mouse model of congenital CMV infection shows defects in olfactory bulb $(\mathrm{OB})$ normal development and pronounced olfactory deficits affecting acuity and discrimination of odorants. These major olfactory deficits occur long before the emergence of auditory deficits through the upregulation of $\mathrm{OB}$ autophagy inducing local neuroinflammation and altered neuron content. Our findings provide new opportunities for designing olfactory means to monitor the possible neurological outcome during congenital CMV infection.

\section{Introduction}

The high seroprevalence of herpes virus type- 5 or cytomegalovirus (CMV) constitutes a major public health concern due to pos-

Received March 21, 2018; revised Sept. 24, 2018; accepted 0ct. 10, 2018.

Author contributions: F.L., L.K., N.T., and P.-M.L. wrote the first draft of the paper; F.L., N.T., and P.-M.L. edited the paper; F.L., N.T., and P.-M.L. designed research; F.L., L.K., S.L., and N.T. performed research; S.W. and P.G. contributed unpublished reagents/analytic tools; F.L., L.K., S.L., and N.T. analyzed data; F.L., N.T., and P.-M.L. wrote the paper.

This work was supported by the Institut Pasteur, Paris (GPF 2015 Microbes and Brain "INFECSMELL"), AG2R-LaMondiale, Inserm Paris VII, and Fondation de l'Avenir (ET4718). We thank Professor Stipan Jonjić for providing the sible sequelae in the fetus and newborn and the absence of vaccines or curative treatments (Teissier et al., 2011; Manicklal et

antibody against murine CMV used in this study; Yoann Madec (Emerging Diseases Epidemiology Unit, Institu Pasteur, Paris) for help in conducting the statistical analysis; the Imagopole-Plateforme d'Imagerie Dynamique (PFID) France-Biolmaging infrastructure, supported by the French National Research Agency (ANR 10-INSB-04-01, Investments for the Future), for advice and access to the (V1000 system; and Zeina Serhal, Laurent Cotter, and Béatrice de Cougny for technical help during the course of this study.

The odorant mixtures are the subject of a patent application (EP3245944 published on November 22, 2017) by Institut Pasteur, Centre National de la Recherche Scientifique, and Assistance Publique-Hôpitaux de Paris on which F.L., P.-M.L., N.T., and S.L. are named as inventors. The remaining authors declare no competing financial interests. 
al., 2013). CMV is transmitted through bodily fluids, likely by the oral and/or the intranasal route (Farrell et al., 2016; Jackson and Sparer, 2018). Infection is usually asymptomatic or can have a flu-type presentation except when transmitted from mother to fetus. CMV belongs to the TORCH class of agents affecting the fetal/neonatal brain that are transmitted in utero or intrapartum. These agents include toxoplasmosis, rubella, herpes simplex and, recently, Zika virus (Coyne and Lazear, 2016). In developed countries, CMV infection is the leading cause of congenital malformations. During pregnancy, CMV infects the placenta with varied outcomes ranging from fetal growth retardation to irreversible birth defects, depending on maternal immunity and gestational age (Pereira and Maidji, 2008; Fornara et al., 2017). Very few prognostic tools for neurosensory sequelae have been developed; these include ultrasound examination for macroscopic brain abnormalities and viral burden at birth (Forner et al., 2015). Approximately $0.5-2 \%$ of newborns are CMV infected and are at high risk of developing learning disabilities and hearing loss, requiring prolonged follow-up care (Williamson et al., 1992; Townsend et al., 2013).

CMV exhibits particular tropism for neural stem cells of the olfactory system of fetuses (van Den Pol et al., 1999; Odeberg et al., 2006; Teissier et al., 2014), thus lesioning the OB, but no study has hitherto examined the impact of the virus on olfaction. Other studies have reported olfactory deficits caused by neurotoxic and viral lesions (Lazarini et al., 2012, 2014; Tian et al., 2016). Because olfactory cues guide many behaviors, most importantly feeding and social behaviors especially at early stages in life, it is plausible that CMV induces behavioral changes resulting from olfactory defects.

Olfaction is the first sensory modality to develop during fetal life in mammals, long before vision and audition (Sarnat and $\mathrm{Yu}$, 2016). Odor processing begins in olfactory sensory neurons (OSNs) of the nasal epithelium, and then proceeds into the OB, followed by primary olfactory cortex (Whitman and Greer, 2009). In humans, OSN olfactory receptors appear at gestational 8 weeks (W8; Bradley and Mistretta, 1975). OSNs are functional in the fetus, as shown by evidence for antenatal learning of odors and olfactory responses of preterm neonates (Engen and Lipsitt, 1965; Schaal et al., 1998, 2000). Olfactory reflexes constitute a useful test in the neurological examination of the term neonates (Sarnat, 1978). Indeed, the neural circuitry underlying the sense of smell is established between the end of the second trimester of pregnancy and early childhood, including a critical period identified in epidemiological studies (Kennedy et al., 2016). Axons from OSNs project to the OB, where they form synapses on the dendrites of mitral/tufted cells, the main projection neurons of the $\mathrm{OB}$, in organized structures called glomeruli. The OB constitutes a usual entry portal for many neurotropic viruses, including $\mathrm{CMV}$, via anterograde transport along OSNs from the nasal epithelium or OB capillaries (Monath et al., 1983; Winkler et al., 2015; Farrell et al., 2016; Wheeler et al., 2017). Fetal OB infection might cause irreversible neuron damage and thus immediate olfactory deficits, preceding the delayed hearing loss that is usually observed. For this reason, early detection of olfactory

*L.K. and S.L. contributed equally to this work.

†N.T. and P.-M.L. are co-senior authors.

Correspondence should be addressed to either Dr. Françoise Lazarini or Dr. Pierre-Marie Lledo, Perception and Memory Laboratory, Institut Pasteur, 25 rue du Dr. Roux, F-75724 Paris Cedex 15, France, E-mail: lazarini@pasteur.fr orpmlledo@pasteur.fr.

https://doi.org/10.1523/JNEUROSCI.0740-18.2018

Copyright $\odot 2018$ the authors $\quad 0270-6474 / 18 / 3810425-14 \$ 15.00 / 0$ impairment might represent a valuable prognostic tool for these congenital infections.

To address the impact of CMV on olfaction, we investigated olfactory behavior in an animal model of congenital CMV infection (Sakao-Suzuki et al., 2014). We show that virus-infected mice display $\mathrm{OB}$ development abnormalities and pronounced olfactory deficits long before the emergence of auditory deficits. These findings provide the rationale for designing new olfactory tests to monitor the possible neurological outcomes of these viral infections.

\section{Materials and Methods}

Ethics statement. All animal procedures were performed in accordance with French legislation and in compliance with the European Communities Council Directives (2010/63/UE, French Law 2013-118, February 6,2013 ) according to the regulations of INSERM and Pasteur Institute Animal Care Committees. The Animal Experimentation Ethics Committee (CETEA 89) of the Pasteur Institute approved this study (20150028). Mice were housed in isolators and manipulated in class II safety cabinets in the Pasteur Institute animal facilities accredited by the French Ministry of Agriculture for performing experiments on live rodents.

CMV transplacental inoculation. Pups of timed Oncins France 1 (OF1) pregnant mice from Charles Rivers Laboratory were intraplacentally inoculated under anesthesia (isoflurane) with $2 \mu \mathrm{l}$ of murine CMV (Smith strain, ATCC VR-1399, at 10(4.75)TCID50/0.2 ml) or PBS at embryonic day 13 (E13) as described previously (Sakao-Suzuki et al., 2014).

Design and groups. Following in utero intraplacental inoculation, mice (total $n=81$ ) were divided in two groups, control (CTL) and CMVinfected mice (CMV) for two separate experimental sets.

Experimental set 1. Experimental set 1 studied the impact of congenital CMV infection on growth, olfaction, olfactory epithelium (OE), OB, and subventricular zone (SVZ) of preweaning mice (see Figs. 1C, 2, 5). This first set comprises a total of 56 inoculated mice (CTL: $n=21$, including 15 males; CMV: $n=35$, including 25 males). Olfaction was assessed 6 and $8 \mathrm{~d}$ after birth using $18 \mathrm{CTL}$ and $19 \mathrm{CMV}$ mice that were chosen randomly (see Fig. 2). The body weight was assessed at day 8 after birth for all the pups (see Fig. 1C). Immunohistochemistry and immunoblot were performed at day 21 after birth using 10 mice per group (six animals for immunohistochemistry and four animals for immunoblot) that were chosen randomly (Fig. 5).

Experimental set 2. Experimental set 2 studied the impact of congenital $\mathrm{CMV}$ infection on hearing, olfaction, $\mathrm{OB}$, and $\mathrm{SVZ}$ of weaning mice (see Figs. $1 D, E, 3,4,6)$. This second set comprises a total of 25 inoculated mice (CTL: $n=13$, including 11 males; CMV: $n=12$, including 8 males). The presence of CMV nucleic acids was assessed by PCR in all the mice at W3 in saliva samples. We chose to investigate hearing and olfactory behavior in only male mice because the sample size for females was too small to reach the needed power for statistical analysis. Hearing was assessed in eight CMV male mice at W4 and W16 after birth and in eight CTL male mice that were chosen randomly (see Fig. $1 E$ ). Olfactory tests were conducted at W4 after birth using all the male mice (CTL: $n=11$; $\mathrm{CMV}: n=8$; see Figs. 3, 4). Following 1 week of training in olfactometers, olfactory tests lasted 7 weeks (see Fig. 1A). Simple and difficult olfactory discrimination (monomolecular odorants and odorant mixtures) was assessed at W5-7 and W8-9, respectively. Olfactory perception was assessed at W10-11. Buried food finding was performed at W12 on the same mice. Olfactory memory was also assessed at W16. Immunohistochemistry was performed at W16 after birth using 15 mice (CTL: $n=7$, including 5 males; CM: $n=8$, including 4 males) that were chosen randomly (see Fig. 6).

Data analysis and statistics. Data were analyzed using GraphPad Prism software. Results are expressed as mean \pm SEM. The statistical test and sample size $(n)$ for each experiment are specified in the figure legends. Sex ratio was compared between groups using Fisher's exact test. Correlation analysis was performed using nonparametric Spearman's test. For odorant discrimination tasks in olfactometers, data were analyzed by two-way repeated-measures ANOVA. Other data were analyzed by Gehan-Breslow-Wilcoxon, Mann-Whitney, or Wilcoxon matched- 
pairs signed-rank tests as appropriate. $p<0.05$ was considered significant.

PCR analysis. To confirm the CMV infection, saliva samples were collected at W3 and harvested for viral DNA extraction using a QIamp DNA micro Kit (Qiagen). A set of oligonucleotide primers from the murine CMV gene was selected on the DNA sequence designed by the ATCC (GenBank accession number U68299). The base sequences coding for UL73 for PCR were as follows: forward primer, 5' -GAA-GGT-TCGTCG-TCG-TCG-AAG-3'; and reverse primer, 5'-TAG-CCG-TGTCTG-AGG-TGA-AGG-3'. Template DNA was prepared by a series of phenol-chloroform extractions (DNA mini kit, Qiagen) and $1 \mu \mathrm{l}$ of sample DNA was added to the reaction mixture before amplification. The final mixture using a PCR kit Qiagen was as follows: tampon $10 \times$ (2.5 $\mu \mathrm{l}), \mathrm{MgCl}_{2}(1 \mu \mathrm{l}), \mathrm{dNTP}(1 \mu \mathrm{l}), \mathrm{H}_{2} \mathrm{O}(13.3 \mu \mathrm{l})$, Taq polymerase $(0.2$ $\mu \mathrm{l})$, forward primer $(1 \mu \mathrm{l})$, reverse primer $(1 \mu \mathrm{l})$, and template DNA (1 $\mu \mathrm{l})$. The DNA reaction mixture was then amplified as follows: step 1, 3 min at $94^{\circ} \mathrm{C} \times 1$ cycle and step $2,3 \mathrm{~min}$ at $94^{\circ} \mathrm{C}, 30 \mathrm{~s}$ at $60^{\circ} \mathrm{C}, 1.5 \mathrm{~min}$ at $72^{\circ} \mathrm{C} \times 35$ cycles. The amplified DNA was electrophoresed on $1.0 \%$ agarose gels, stained with ethidium bromide, and photographed.

Odorants. All nonsocial odorants were monomolecular compounds from Sigma-Aldrich dissolved in water or mineral oil as indicated. Citral has lemon scent; n-butanol has a rancid scent; D-limonene has an orange scent; citronellal has a citronella scent; anethol has an anise scent; and isoamylacetate has a banana scent.

Auditory brainstem responses (ABRs). Hearing loss was assessed using ABR (OtoPhylab, RT Conception) as described previously (Nguyen et al., 2009; Scimemi et al., 2014). Needle electrodes were placed subcutaneously under anesthesia with ketamine $(40 \mathrm{mg} / \mathrm{kg}$ ) and xylazine $(4 \mathrm{mg} /$ $\mathrm{kg})$. The reference electrodes were inserted beneath the pinna of the ears, the ground beneath the skin of the neck, and the active electrode beneath the skin of the back. Headphones with appropriate earplugs were used as acoustic transducers. Clicks were delivered in range of 12-30 Hz. Filter settings were at $150-3000 \mathrm{~Hz}$. Responses from 1000 sweeps were averaged at each intensity level. Initially, the click intensity was reduced by 20 or $10 \mathrm{~dB}$ steps sound pressure level (SPL) and then by $5 \mathrm{~dB}$ SPL steps near threshold. A contralateral auditory masking was used for high-intensity stimulations $(>45 \mathrm{~dB})$. The threshold was defined as the lowest intensity at which a clear IV waveform was visible in the evoked trace and was determined by visual inspection of the responses in blind of the mouse group.

Recording and analysis of ultrasonic vocalizations. To assess olfaction in 6- to 8-d-old pups, we used custom-made olfactometers (Lemasson et al., 2005) to measure the number of ultrasonic vocalizations emitted after isolation as an index of odorant detection. The recording of ultrasonic calls began $30 \mathrm{~s}$ after placing the pup in the custom-made chamber isolator of olfactometers as described previously (Lemasson et al., 2005). Ultrasonic vocalizations were detected using an ultrasonic microphone connected to a bat detector (frequency range 10-130 kHz, Magenta BAT5 digital bat detector, RSPB) that converts ultrasonic sounds to the audible frequency range. Using the broadband $60 \mathrm{kHz}$ output of the detector, ultrasonic calls were sampled, recorded, and analyzed using Audacity open software (www.audacityteam.org). Ultrasonic emissions were recorded during the $5 \mathrm{~min}$ isolation time of the pup into the olfactometer during three successive test periods: the first period without any odorant ( $1 \mathrm{~min})$, the second period with exposure to social or nonsocial odorant $(1 \mathrm{~min})$, and the last period with exhaust odorant $(1 \mathrm{~min}$ and $30 \mathrm{~s}$ ). The social odorant was a male scent from $10 \mathrm{~g}$ of soiled bedding from a group of six unfamiliar male adult OF1 mice. The nonsocial odorant was an odorant scent delivered from $10 \mathrm{ml}$ of liquid $10 \%$ mineral oil dilution of citral. After testing, pups were immediately put back with their mothers. The mean rate of ultrasonic emissions (calls/min) was computed for each time block.

Buried food-finding test. To assess olfaction in adult mice, we used the buried food finding test after $20 \mathrm{~h}$ of food deprivation as described previously (Lazarini et al., 2012). Approximately 10 pieces of "Coco Pops" cereal were hidden in the corner of the test cage under the bedding. The mouse was placed in the opposite corner and the latency to find the food within a $15 \mathrm{~min}$ period was recorded (defined as the time to locate cereals and start digging). Thirteen minutes later, mice performed the same test but with visible cereal positioned upon the bedding.

Olfactometry in weaning mice. Mice were partially water deprived by receiving $1-2 \mathrm{ml} / \mathrm{d}$ of water for 1 week and then trained on a "go-no go" discrimination task in computer-controlled olfactometers with custommade mouse chamber isolator. As described previously (Alonso et al., 2012), mice were trained to respond to the presence of an odorant (positive stimulus, $\mathrm{S}+$ ) by licking the water delivery tube situated out of the odorant sampling port ( $5 \mathrm{~cm}$ distance). They were also trained not to respond on the presentation of another odorant or solvent (negative stimulus, $\mathrm{S}-$ ). A single stimulus ( $\mathrm{S}+$ or $\mathrm{S}-$ ) was randomly presented at each trial. Each series of 20 trials (block) comprised 10 presentations of the rewarded odorant and 10 presentations of the nonrewarded odorant.

Licking response following an S+ trial and no licking following an Strial were scored as correct and called hit and correct rejection, respectively. Approximately $10 \mu \mathrm{l}$ of water were delivered as a reward in a hit. A licking response following an $\mathrm{S}-$ trial and no licking following an $\mathrm{S}+$ trial were scored as error and named false alarm and miss, respectively. Accuracy (percentage of correct responses) was scored for each series of 20 trials [(hits + correct rejections) $/ 20 \times 100]$. Olfactory performances were assessed using monomolecular odorant compounds and binary odorant mixtures. Mice were given a session of $8-10$ series of 20 trials per day. All odorants were diluted just before the experiments and their concentrations are given as the dilution of the odorant in the saturator bottles.

Odorant detection threshold. Mice were trained in olfactometers to recognize n-butanol as the rewarded stimulus $(\mathrm{S}+)$. Mice have to detect successively descending decimal concentrations of $\mathrm{n}$-butanol $(\mathrm{S}+)$ diluted in water. In each session, water served as the $S-$. Mice were given one to two sessions per day with one decimal dilution of the odorant per session. The session ended at the criterion performance achievement ( $\geq 75 \%$ of correct response in the series of 20 trials). If the criterion performance was not achieved in two successive sessions with the same odorant dilution, then the preceding dilution was considered as the detection threshold.

Odorant discrimination tasks. Mice were trained to discriminate between: (1) D-limonene (dilution $10^{-2}$ in mineral oil, $S+$ ) and citronellal (dilution $10^{-2}$ in mineral oil, S) (simple discrimination task); (2) D-limonene (dilution $10^{-2}$ in mineral oil, $\mathrm{S}+$ ) and anethol (dilution $10^{-2}$ in mineral oil $\mathrm{S}-$ ) (simple discrimination task); and (3) $0.1 \%$ isoamylacetate (dilution $10^{-3}$ in water, $\mathrm{S}+$ ) and anethol ( $\mathrm{S}-$ ) diluted in mineral oil (simple discrimination task).

Then, olfactory discrimination performance was assessed for two isoamylacetate-anethol mixture tasks (difficult discrimination task). In the first task, $\mathrm{S}+$ was a solution of $0.8 \%$ isoamylacetate and $0.2 \%$ anethol and $\mathrm{S}-$ was a solution of $0.2 \%$ isoamylacetate + and $0.8 \%$ anethole. In the second task, $\mathrm{S}+$ was a solution of $0.6 \%$ isoamylacetate and $0.4 \%$ anethole and S- was a solution of $0.4 \%$ isoamylacetate and $0.6 \%$ anethol.

Long-term memory test. Mice were given four daily training sessions of eight blocks of 20 trials for D-limonene anethol discrimination task (S+ was a solution of D-limonene at dilution 10-2 in mineral oil and $\mathrm{S}$ - was a solution of anethol dilution 10-2 in mineral oil). Mice were then left for $30 \mathrm{~d}$ in their home cages and subjected to partial water deprivation for the last $7 \mathrm{~d}$. No water was given on day 29 ; the following day, each mouse was subjected to a 20-trial memory test for the two odorant tasks. No reinforcement (reward) was given for correct responses in this session.

Immunohistochemistry, confocal imaging, and quantification. Mice were anesthetized with sodium pentobarbital ( $100 \mathrm{mg} / \mathrm{kg}$, i.p., Sanofi) and perfused transcardially with a solution containing $0.9 \% \mathrm{NaCl}$ and heparin $\left(5 \times 10^{3} \mathrm{U} / \mathrm{ml}\right.$, Sanofi) followed by $4 \%$ paraformaldehyde in phosphate buffer. OE and brain were removed and postfixed by incubation in the same fixative overnight. OE were cryoprotected by incubation in 30\% sucrose in PBS overnight and then embedded in Tissue-tek (Sakura). OE 20- $\mu$ m-thick transverse sections were obtained using a cryostat (CM3050S, Leica) and were thaw-mounted onto coated glass slides (Superfrost Plus). Forty-micrometer coronal brain sections were obtained using a vibrating microtome (VT1000S, Leica). Immunostaining was performed on free-floating sections for brain slices and fixed sections for $\mathrm{OE}$ as described previously (Siopi et al., 2016). Sections were 
Table 1. Detailed information on the primary antibodies used in this study

\begin{tabular}{llll}
\hline Antibody (anti-) & Manufacturer, catalog \# & Marker of & Working dilution \\
\hline Actin & Sigma-Aldrich, A5441 & Housekeeping protein & $1: 6000$ \\
Atg5 & Cell Signaling Technology, 12994 & Autophagy initiation & $1: 1000$ \\
Beclin1 & Cell Signaling Technology, 3495 & Autophagosome induction & $1: 1000$ \\
CB & Swant, 300 & Calbindin interneurons & $1: 2000$ \\
CMV & S. Jonjic gift & IE1 protein of the murine virus & $1: 1000$ \\
CR & Swant, 7699/3H & Caretinin interneurons & $1: 2000$ \\
Active casp3 & Cell Signaling Technology, asp175 & Apoptotic cells & $1: 300$ \\
CD68 & Serotec, MCA1957GA & Activated microglia & $0.5 \mu$ g/ml \\
Iba1 & Wako Chemicals, 016-20001 & Microglia & $1: 500$ \\
Ki67 & Abcam, 15580 & Proliferating cells & $1: 1000$ \\
Lamp1 & Abcam, 24170 & Lysosomes (autophagy) & $1: 1000$ \\
LC3 & Sigma-Aldrich, L7543 & Autophagic flux & $1: 2000$ \\
0MP & Wako, 544-10001 & Olfactory sensory neurons & $1: 1000$ \\
P62 & Abnova, H00008878-M01 & Autophagic flux & $1: 1000$ \\
pAMPK1 & Cell Signaling Technology, 2531 & Metabolic signalling & $1: 1000$ \\
pmTOR & Cell Signaling Technology, 2971 & Immune signalling & $1: 1000$ \\
TH & ImmunoStar, 22941 & Dopaminergic neurons & $1: 4000$ \\
\hline
\end{tabular}

blocked in $0.2 \%$ Triton X-100, $4 \%$ bovine serum albumin (BSA, SigmaAldrich), and $2 \%$ goat serum and incubated overnight with primary antibodies at $4^{\circ} \mathrm{C}$ followed by an incubation step with secondary antibodies (biotinylated or Alexa Fluor-conjugated secondary antibodies, Jackson ImmunoResearch Laboratories) at room temperature. The primary antibodies used in this study and their working dilutions are listed in Table 1. For immunolabeling of either murine CMV (Cekinović et al., 2008), tyrosine hydroxylase (TH), anti-ionized calcium binding adaptor molecule (Iba1), and cluster of differentiation (CD) 68, brain sections were preincubated for $20 \mathrm{~min}$ in citrate buffer $0.1 \mathrm{M}, \mathrm{pH} 9.0$, at $80^{\circ} \mathrm{C}$. Fluorescent sections were stained with the nuclear dye $4^{\prime}, 6^{\prime}$-diamidino2-phenylindole (DAPI) and then mounted in Fluoromount solution (eBiosciences). Immunoperoxidase-labeled cells were developed using the $\mathrm{ABC}$ system (Vector Laboratories) and 3,3'-diaminobenzidine $(0.05 \%$, Sigma-Aldrich) as chromogen and then sections were mounted in Depex medium.

For cell counting, six OE consecutive slices from the posterior nasal cavity and four to eight brain slices separated by $120 \mu \mathrm{m}$ were selected for each animal. Whole OE, OB, or SVZ mosaics were obtained using an Olympus BX51 microscope (20× objective) and Compix imaging software (Hamamatsu Photonics) for the analysis of immunoperoxidaselabeled cells or the spinning disk confocal microscope Cell Voyager (CV1000, Yokogawa) for the analysis of immunofluorescent-labeled cells. The borders of the OE septum, SVZ, rostral migratory stream (RMS), glomerular layer (GL), and granule cell layer (GCL) were delineated blinded to the results. The glomerulus area was assessed by measuring the area occupied by olfactory marker protein (OMP). The thickness of the OE was measured on each side of the dorsal septum as the total distance between the basement membrane and the top of the ciliary layer in $0.1 \%$ cresyl violet solution (Nordic BioSite)-stained sections. Positive cells were automatically counted using the "spot detector" tool of the Icy open source platform (de Chaumont et al., 2012). For the quantification of OSN-positive cells in the OE, six or seven zones between the basement membrane and the top of the ciliary layer were analyzed per section of the olfactory mucosa situated in the dorsal septum of the posterior nasal cavity zones.

Protein blotting and quantification. OBs were dissected, snap frozen in liquid nitrogen, and lysed in RIPA lysis buffer ( $25 \mathrm{~mm}$ Tris-HCl, pH 7.6, $150 \mathrm{~mm} \mathrm{NaCl}, 1 \% \mathrm{NP}-40,1 \%$ sodium deoxycholate, $0.1 \%$ SDS) (Pierce/ Thermo Scientific), Protease Complete (Roche), and phosphatase (phosSTOP, Roche) inhibitors. Protein concentration was measured with Pierce BCA protein Assay Kit. Tissue lysates were mixed with $4 \times$ NuPage LDS loading buffer (Invitrogen) and $25 \mu$ g of protein was loaded onto $4-12 \%$ SDS-PAGE gradient gels (Invitrogen) and subsequently transferred by semidry or wet transfer onto a PVDF membrane (Transblot Turbo Mini PVDF, Bio-Rad). The blots were blocked in 5\% BSA in Tris-buffered saline with Tween and incubated overnight with primary antibodies at $4^{\circ} \mathrm{C}$. Primary antibodies used in this study and their work- ing dilutions are listed in Table 1 . To detect protein signal, the following horseradish peroxidase (HRP)-conjugated secondary antibodies were used: goat anti-rabbit $\operatorname{IgG}(\mathrm{H}+\mathrm{L})$-HRP conjugate $(1: 6000,1706515$, Bio-Rad) and goat anti-mouse IgG1 heavy chain (HRP) (1:6000, ab97240, abcam). Chemiluminescence detection of proteins was performed with Luminata Crescendo Western HRP Substrate (Merck Millipore) with a Chemidoc Imaging System (Bio-Rad). Bands were quantified using Fiji software.

\section{Results}

Impact of congenital CMV infection on growth and hearing In utero intraplacental inoculation of murine CMV was performed in timed pregnant mice (E13) under deep anesthesia (Fig. $1 A, B)$. Earlier studies demonstrate that this model recapitulates many features of congenital human CMV infection (SakaoSuzuki et al., 2014). First, we confirm that transplacental CMV inoculation causes fetal infection using saliva PCR assay for CMV genome detected in virus-inoculated mice, but not in CTL mice (saliva specimen collected at W3: $n=12 \mathrm{CMV}, n=13 \mathrm{CTL}$ ). Second, we found a strong male bias at birth for both CTL and CMV groups (male/female ratio: CTL: 3.25; CMV: 2.36, Fisher's exact test, $p=0.62, n=34 \mathrm{CTL}, n=47 \mathrm{CMV}$ ). These findings suggest a differential survival rate of embryos due to both the transplacental inoculation and the virus injection. In humans, the sex ratio seems more favorable to girls in case of congenital CMV infection (Watt et al., 2016). Third, we confirmed that our model induces developmental retardation reminiscent of congenital CMV infection in humans (Fig. $1 C$, mean \pm SEM body weight at $8 \mathrm{~d}$ : CTL: $7.065 \pm 0.1 \mathrm{~g}$; CMV: $6.44 \pm 0.11 \mathrm{~g}$, MannWhitney $\mathrm{U}(52)=151, p=0.0005, n=21 \mathrm{CTL}, n=35 \mathrm{CMV})$. Severe growth retardation was observed in $25 \%$ of 8 -postnatal day-old offsprings exposed to infection in utero (nine pups of 34), consistent with a previous report (Li and Tsutsui, 2000). Third, we confirmed that this model develops a progressive hearing loss phenotype reminiscent of what has been reported in infants with congenital CMV infection (Fig. 1 D, E, CMV vs CTL). Recordings of ABRs show an age-dependent sensorineural hearing loss in CTL and CMV-infected mice (Fig. 1E, W4 vs W16: hearing threshold: CTL: Wilcoxon matched-pairs signed-rank test, $p=$ 0.0156; CMV: Wilcoxon matched-pairs signed-rank test, $p=$ 0.0078, $n=8 \mathrm{CTL}, n=8 \mathrm{CMV})$. ABRs showed no difference in hearing thresholds between control and infected mice at W4 after birth, but increased by $\sim 20 \mathrm{~dB}$ in W16 infected mice (Fig. 1E, CMV vs CTL: hearing threshold: W4: Mann-Whitney $U_{(14)}=24$, $p=0.44$; W16: Mann-Whitney $U_{(16)}=2, p=0.0005, n=8 \mathrm{CTL}$, $n=8 \mathrm{CMV}$ ), consistent with previous reports (Juanjuan et al., 2011; Schachtele et al., 2011; Bradford et al., 2015). Altogether, these findings indicate that transplacental CMV inoculation causes fetal infection, growth retardation, and progressive hearing deterioration in mice.

\section{Impact of congenital CMV infection on neonate olfaction}

To address olfactory abilities in very young pups following congenital CMV infection, we recorded their ultrasonic vocalizations emitted when exposed to odorants in an olfactometer (Fig. 2). We found that pups with placental CMV infection exhibited impaired olfactory perception as early as $6 \mathrm{~d}$ after birth (Fig. 2). After separation from their mothers and isolation in an olfactometer chamber, preweaning pups aged $6-8 \mathrm{~d}$ produced ultrasonic calls that promoted mother-offspring interaction (Fig. $2 A-F$ ), consistent with previous reports (Branchi et al., 1998; Lemasson et al., 2005). CMV-infected pups also emitted such ultravocalizations following isolation as a distress signal (Fig. 2E,H,I). No 

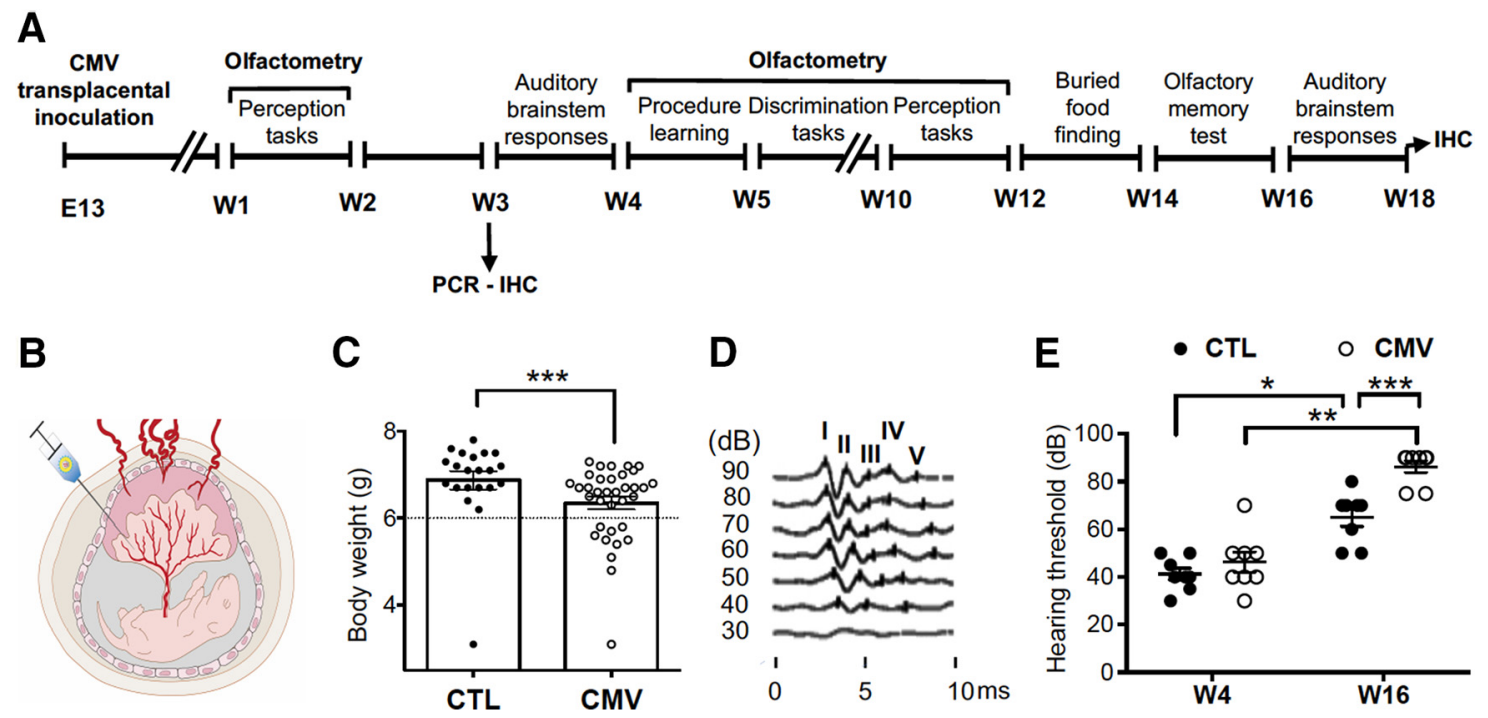

Figure 1. Impact of CMV congenital infection on hearing. A, Timetable of the experiments. Mice were infected with CMV or received PBS at E13. They were analyzed using olfactometers and with buried food-finding tests. Their ABRs were recorded twice, at W4 and W16. $\boldsymbol{B}$, Animal model of CMV infection in pregnancy. Murine CMV or PBS was intraplacentally inoculated in each embryo of pregnant mice under deep anesthesia. C, Body weight of the 8-postnatal day-old mice after infection with murine CMV at day 13 of gestation ( $n=21$ CTL, $n=35$ CMV). CTL mice were injected with saline only. Outliers were identified by ROUT. Variances between the CTL and CMV groups without outliers are different $\left(F_{(33,19)}=2.433,{ }^{*} p<0.05\right)$, underlying the growth retardation of $9 / 34 \mathrm{CMV}$ pups. $\boldsymbol{D}$. Click-evoked ABR waveforms at different sound intensities. $\boldsymbol{E}$, ABR hearing thresholds for a click. $n=8$ male mice per group. $p$-values were calculated by Mann-Whitney test $(\boldsymbol{C}, \boldsymbol{D}$ : comparison between (TL and CMV groups) or Wilcoxon matched-pairs signed-rank test (D: comparison between W4 and W16 for each mouse group). ${ }^{*} p<0.05$; ${ }^{* *} p<0.01$, ${ }^{* * *} p<0.001$; mean \pm SEM in bar graphs.
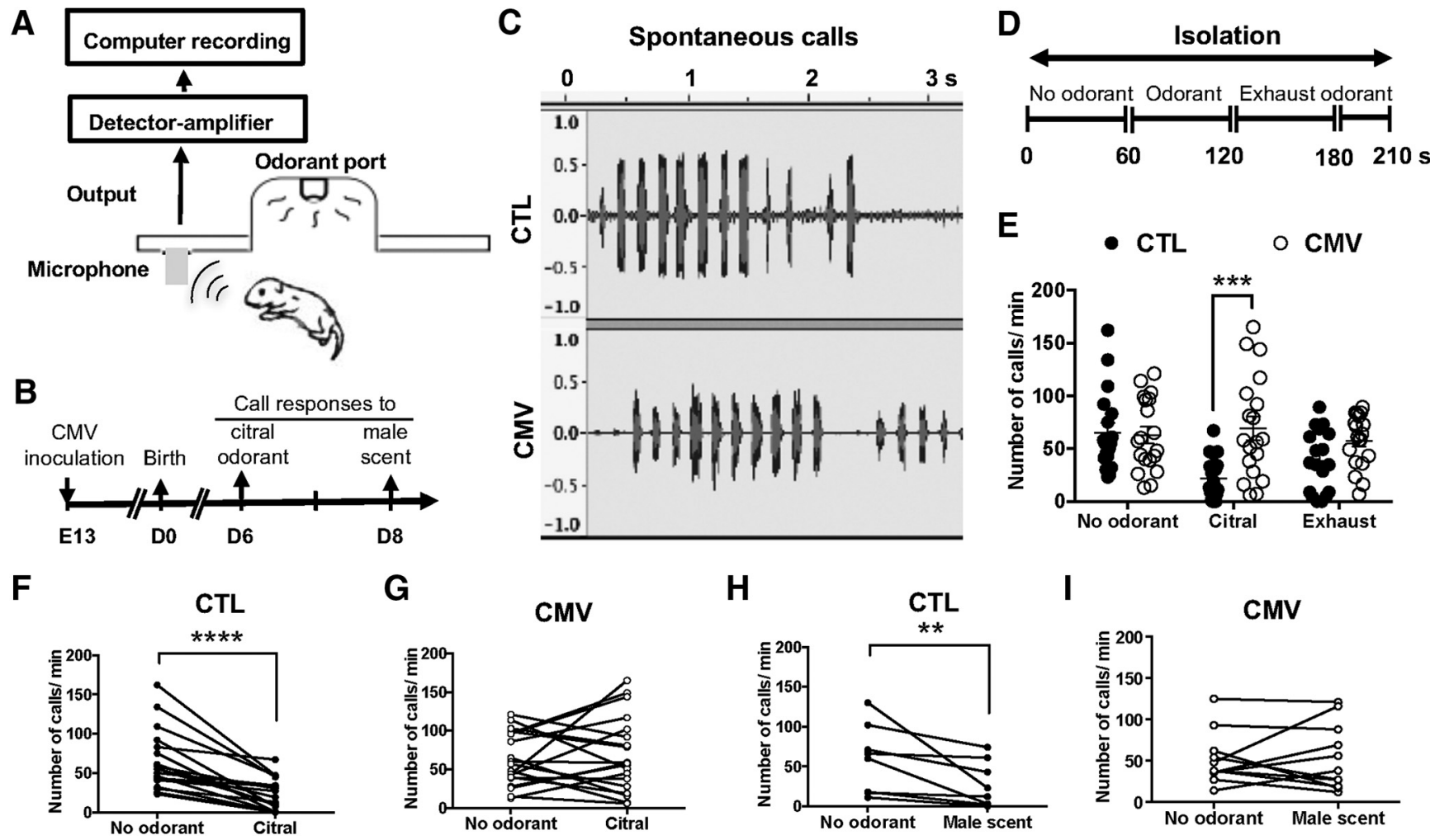

Figure 2. Impact of CMV congenital infection on neonate olfaction. $\boldsymbol{A}$, Emission and quantitation of ultrasonic vocalizations. The recording of ultrasonic calls began $30 \mathrm{~s}$ after placing the pups in the test chamber of the olfactometer. Ultrasonic vocalizations were detected using an ultrasonic microphone connected to a bat detector that converts ultrasonic sounds to the audible frequency range. $\boldsymbol{B}$, Timetable of the experiments. Mice were infected in utero with CMV or received PBS at E13. They were analyzed using olfactometers at 6 and $8 \mathrm{~d}$ after birth. C, Typical wave traces of spontaneous call series from preweaning 6-day-old pups after congenital CMV infection. CTL mice were inoculated with PBS only. $\boldsymbol{D}$, Experimental paradigm. Ultrasonic emission responses were recorded during the first period without odorant (1 $\mathrm{min})$, followed by a period of odorant exposure (1 $\mathrm{min}$ ) and finally the last period of exhaust odorant (1 min and $30 \mathrm{~s})$. $\boldsymbol{E}-\boldsymbol{G}$, Emission of ultrasonic calls for citral odorant on day 6 after birth $(n=18 \mathrm{CTL}, n=19 \mathrm{CMV})$. $\boldsymbol{H}, \mathbf{I}$, Emission of ultrasonic calls for male scent odorant on day 8 after birth $(n=8 \mathrm{CTL}, n=11 \mathrm{CMV})$. $p$-values were calculated by Mann-Whitney test $(\boldsymbol{E})$ or Wilcoxon matched-pairs signed-rank test $(\boldsymbol{H}, \boldsymbol{I}){ }^{* *} p<0.01,{ }^{* * *} p<0.001$, ${ }^{* * *} p<0.0001$; mean \pm SEM in $\boldsymbol{E}$. 
A

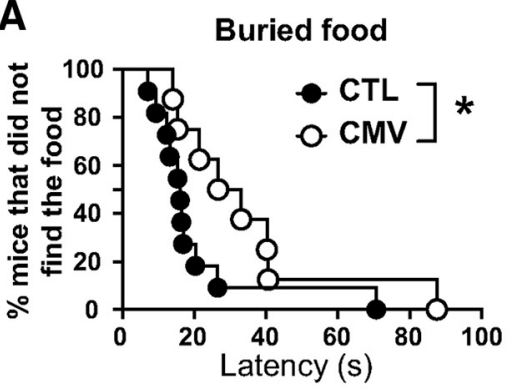

C

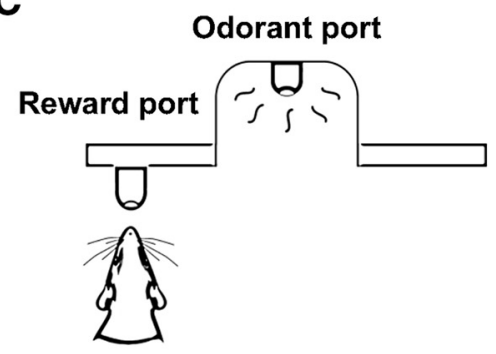

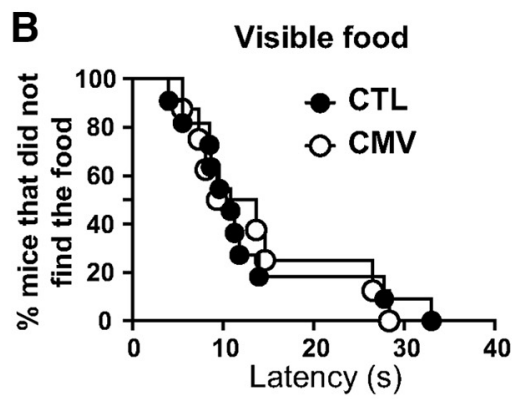

D

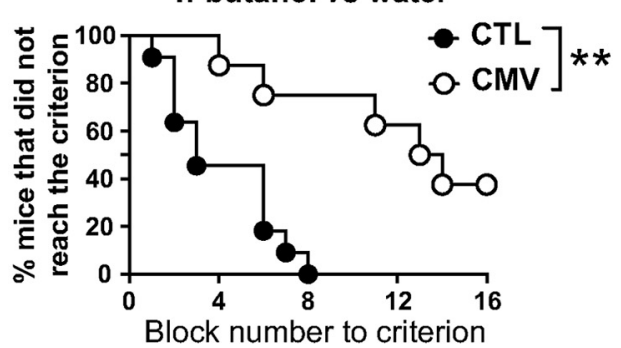

E

Olfactory threshold

n-butanol vs water
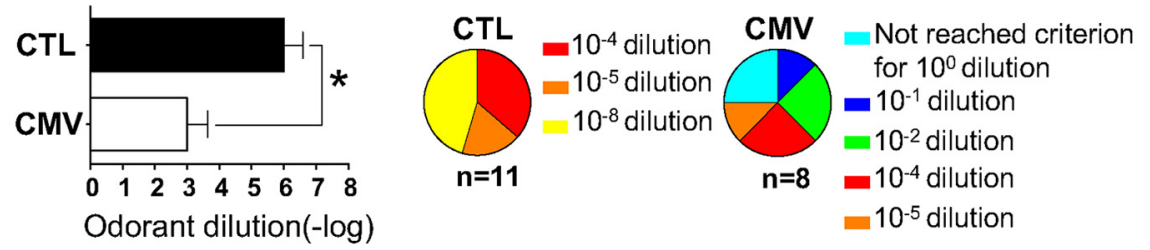

Figure 3. Impact of CMV congenital infection on olfactory perception in adult male mice. $\boldsymbol{A}, \boldsymbol{B}$. Latency to find the buried $(\boldsymbol{A})$ or visible $(B)$ food reward in the buried food-finding test. Results are percentage of mice that did not find the food over a $15 \mathrm{~min}$ period. $C_{,} \mathrm{G}_{0}-$ no go procedure. The olfactometer isolator comprises an odorant sampling port and a water delivery tube to reward mice. Animals are trained to distinguish between 2 odorants: a positive stimulus $(S+)$ and a negative stimulus $(S-)$. A licking response following an $S+$ trial and no licking following an $S$ - trial were scored as correct. $D$, percentage of mice that did not reach the criterion performance ( $75 \%$ correct responses in the block) on a discrimination task using n-butanol ( $10^{-3}$ dilution) and its solvent. A block is a series of 20 trials with random $10 S+$ and $10 S-$. $\boldsymbol{E}$, Effects of congenital CMV infection on olfactory detection. Results are expressed as detection thresholds ( $-\log _{10}$ of odorant dilution; mean \pm SEM) for $n$-butanol (left) or the percentage of mice for the last dilution performance criterion (right). Results in $\boldsymbol{A}, \boldsymbol{B}$, and $\boldsymbol{F}$ are expressed as the mean \pm SEM of correct responses. $n=8 \mathrm{CMV}, n=11 \mathrm{CTL}$. $p$-values were calculated by Gehan-Breslow-Wilcoxon test $(\boldsymbol{A}, \boldsymbol{B}, \boldsymbol{D})$ and Mann-Whitney test $(\boldsymbol{E}){ }^{*} p<$ $0.05 ;{ }^{* *} p<0.01$.

difference in the number of emitted ultravocalizations was found between CTL and CMV-infected pups (Fig. 2E, CTL vs CMV: number of calls/min in the first minute of isolation with no olfactometer emission of odorant: Mann-Whitney $U_{(35)}=169.5$, $p=0.97, n=18 \mathrm{CTL}, n=19 \mathrm{CMV}$ ), as well as between male and female pups of the two groups (data not shown). As expected and consistent with previous studies (Branchi et al., 1998; Lemasson et al., 2005), CTL pups decreased their emission of calls in response to exposure to nonsocial or social odorant molecules such as citral or male scent, respectively (Fig. $2 F, H$, no odorant vs citral, Fig. 2F: number of calls/min: Wilcoxon matched-pairs signed-rank test, $p<0.0001, n=18$ CTL; no odorant vs male scent, Fig. $2 \mathrm{H}$ : number of calls/min: Wilcoxon matched-pairs signed-rank test, $p<0.0078, n=8 \mathrm{CTL})$. In contrast, congenital CMV infection impaired the ultrasonic call responses triggered by the two scents, indicating an alteration of olfactory perception induced by the virus (Fig. 2E, G,I). Figure 2, $E$ and $G$, reveals olfactory dysfunction as seen by the lack of inhibition of ultravocalizations when pups were exposed to citral as early as the sixth day after birth (Fig. 2E, CTL vs CMV: number of calls/min when citral exposition: Mann-Whitney $U_{(35)}=61.5, p=0.0005, n=$
18 CTL, $n=19$ CMV; Fig. 2G, CMV: number of calls / $\mathrm{min}$ when citral exposition, Wilcoxon matched-pairs signedrank test, $p=0,67, n=19 \mathrm{CMV})$. Similarly, Figure $2 I$ shows impairment in detecting male scent in CMV-infected mice (no odorant vs male scent: number of calls/min: Wilcoxon matched-pairs signed-rank test, $p>0.99, n=11 \mathrm{CMV})$.

Impact of congenital CMV infection on odorant detection in weaning mice Given the early detrimental effects of congenital CMV infection in neonate olfaction, we assessed olfactory-driven behavior of infected mice at W16 after in utero viral inoculation to investigate potential long-lasting effects. Consistent with defective olfaction, CMV-infected mice exhibited impaired hidden food search (Fig. 3A, CMV vs CTL: latency: Gehan-Breslow-Wilcoxon test, $\chi^{2}=4.032$, $p=0.045, n=11$ male CTL, $n=8$ male $\mathrm{CMV}$ ), but not when food was made visible (Fig. 3B, CMV vs CTL: latency: Gehan-Breslow-Wilcoxon test, $\chi^{2}=$ 0.007, $p=0.935, n=11$ male CTL, $n=8$ male CMV). This latter control paradigm indicates that the deficit in this behavioral test is genuinely olfactory and not related to another modality. Three olfactory dimensions could be compromised by CMV infection: odorant detection, discrimination, and/or learning. To specify whether they were equally impaired, congenitally infected mice were tested 1 month after birth using automated olfactometers (Fig. $3 C)$.

We investigated olfactory sensitivity by determining the detection threshold for n-butanol odorant using the descending method of limits in a two-odorant rewarded discrimination task. Mice were subjected to two sessions per day with a one decimal dilution of the odorant per session. As shown in Figure 3D, CMV-infected mice needed more trials to learn to distinguish between n-butanol and its water solvent (CMV vs CTL: block number to criterion: Gehan-Breslow-Wilcoxon test, $\chi^{2}=8.945$, $p=0.028, n=11$ male CTL, $n=8$ male CMV). CMV infection resulted in an increase of approximately three orders of magnitude in the detection threshold of the odorant (Fig. 3E, left, CMV vs CTL: threshold: Mann-Whitney $U_{(15)}=9, p=0.0104, n=11$ male CTL, $n=6$ male CMV). Although all control mice were able to detect diluted n-butanol, two CMV-infected mice of eight were unable to achieve the performance criterion even for pure n-butanol (Fig. 3E, right). We therefore conclude that congenital CMV infection dramatically impairs odorant detection in neonate as well in adult mice, thus affecting several critical olfactory-driven behaviors.

\section{Impact of congenital CMV infection on odorant} discrimination and olfactory memory

Given the strong effects of CMV on olfactory perception, we investigated the possible impact on olfactory discrimination. The same paradigm was used in weaning male mice for simple olfac- 


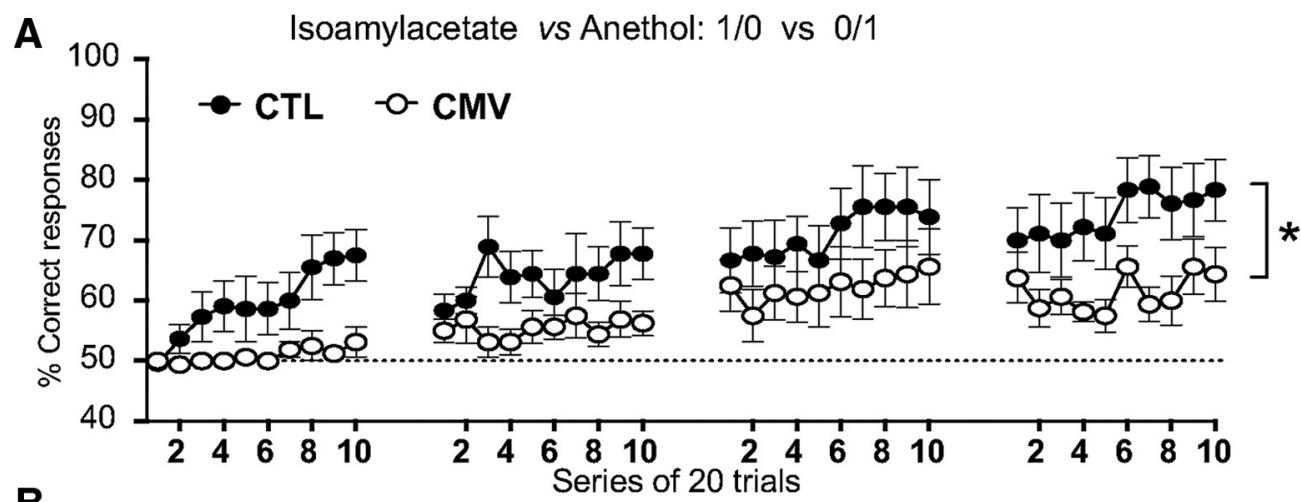

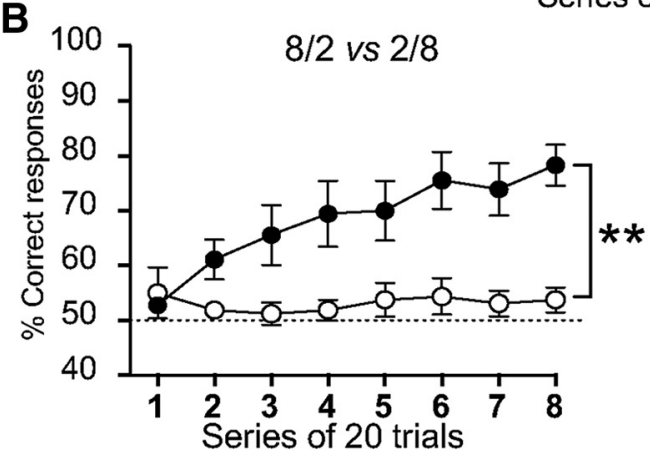

C Isoamylacetate vs Anethol

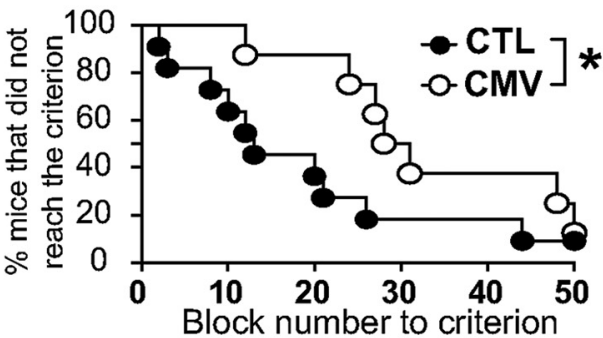

E

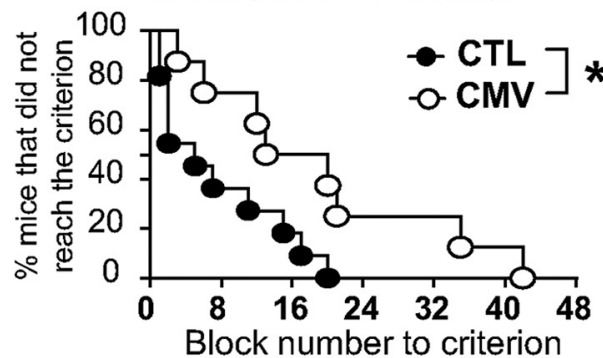

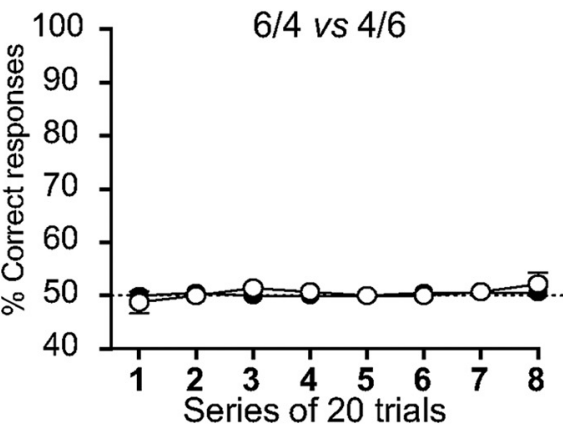

D-Limonene vs Citronellal

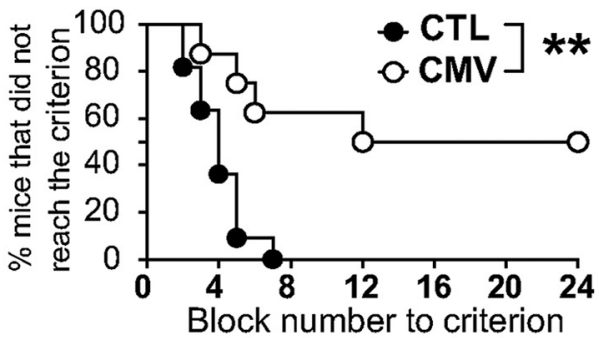

$\mathbf{F}$

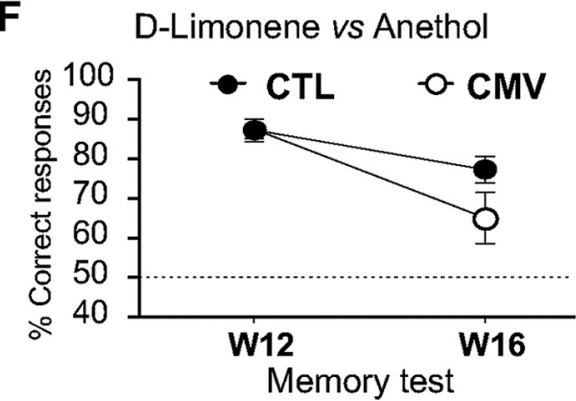

Figure 4. Impact of CMV congenital infection on olfactory discrimination in adult male mice. $\boldsymbol{A}, \boldsymbol{B}$, Graph depicting the percentage of correct responses in each block of the easy $(\boldsymbol{A})$ discrimination task between isoamylacetate $(S+)$ and anethol $\left(S_{-}\right)$or the difficult $(\boldsymbol{B})$ discrimination tasks between their binary mixtures. The mixture ratio of isoamylacetate and anethol is indicated on the graph. $\boldsymbol{C}-\boldsymbol{E}$, Percentage of mice that did not reach the performance criterion for the discrimination task between isoamylacetate and anethol $(\boldsymbol{C})$, o-limonene and citronellal (D), and D-limonene and anethol $(\boldsymbol{E}) . \boldsymbol{F}$, Long-term memory test. To assess olfactory memory, mice were trained during 5 consecutive days to recall distinguishing D-limonene and anethol. Mice were then retested at W16 following the end of the training session (W12). In $A, B$, and $\boldsymbol{F}$, a score of $50 \%$ corresponds to the success rate expected on the basis of chance alone (dashed line). Results in $A, B$, and $\boldsymbol{F}$ are expressed as the mean \pm SEM of correct response. $n=8 \mathrm{CMV}, n=11$ CTL. $p$-values were calculated by ANOVA with repeated-measures $(\boldsymbol{A}, \boldsymbol{B})$, Gehan-Breslow-Wilcoxon test $(\boldsymbol{C}-\boldsymbol{E})$, or Mann-Whitney test $(\boldsymbol{F}) .{ }^{*} p<0.05,{ }^{* *} p<0.01$.

tory discrimination between two odorants and for difficult olfactory discrimination between binary mixtures of odorants (Fig. 4) using strong concentrations. We found that CMV-infected mice have altered odorant discrimination, in particular when binary mixtures of monomolecular odorants were used (i.e., difficult task). CMV infection alters the ability of mice to learn to discriminate between isoamylacetate and anethol (Fig. 4A, repeated- measures two-way ANOVA, $\left.F_{\text {virus }(1,17)}=5.837, p=0.027\right)$. In the difficult discrimination task of isoamylacetate-anethol mixtures (Fig. $4 B$ ), the $6 / 4$ versus $4 / 6$ mixtures could not be correctly discriminated by CTL and CMV-infected mice (Fig. $4 B$, right). When using more contrasted mixture (e.g., $8 / 2$ vs $2 / 8$ mixtures) only CTL mice discriminated the odorants, whereas CMVinfected animals performed the task at chance level (Fig. 4B, left, 
repeated-measures two-way ANOVA, $F_{\text {virus }(1,17)}=14.63, p=$ $0.0014)$. Even when infected mice successfully completed twoodorant discrimination tasks in easy problems (simple discrimination between two odorants), they needed more trials to complete these tasks. CMV-infected mice required more trials than CTL to learn to discriminate between isoamylacetate and anethol (Fig. 4C, CMV vs CTL: block number to criterion: Gehan-Breslow-Wilcoxon test, $\chi^{2}=4.56, p=0.033, n=11$ male CTL, $n=8$ male CMV), D-Limonene and Citronellal (Fig. $4 D$, CMV vs CTL: block number to criterion: Gehan-Breslow-Wilcoxon test, $\chi^{2}=7.425, p=0.006, n=11$ male CTL, $n=8$ male $\mathrm{CMV}$ ) or D-limonene and anethol (Fig. $4 E$, CMV vs CTL: block number to criterion: Gehan-Breslow-Wilcoxon test, $\chi^{2}=4.735$, $p=0.03, n=11$ male CTL, $n=8$ male CMV).

Analysis of long-term olfactory memory suggests no differences between CMV-infected and CTL mice despite a trend for lower score in infected animals (Fig. $4 F$, CMV vs CTL: percentage correct responses at W16: Mann-Whitney test, $U_{(17)}=27.5, p=$ $0.1788, n=11 \mathrm{CTL}, n=8 \mathrm{CMV})$. Altogether, these data indicate that $\mathrm{CMV}$-inoculated mice exhibit poorer odorant detection and olfactory discrimination, whereas their olfactory memory seems intact.

\section{Congenital CMV infection leads to OB neuroinvasion, apoptosis, and inflammation}

Bridging the nose to higher brain structures, the OB circuit constitutes the first central relay station of the olfactory system. The olfactory deficits we reported here may result from damage to the $\mathrm{OB}$ circuit by CMV-induced lesions in the placenta and/or impairment of the olfactory system (Fig. 5A). Immunohistochemical analysis of brains at W3 after birth reveal viral expression in all the OB layers of CMV-infected male mice (Fig. $5 B$ ), as well all in the SVZ (Fig. 5D, down), consistent with previous studies (Han et al., 2007; Cekinović et al., 2008). These data indicate that, in our animal model, transplacental CMV inoculation causes embryo infection, neuroinvasion, and long-term viremia in the OB lasting at least 3 weeks after birth. Moreover, immunohistochemistry and immunoblot experiments revealed that viral expression in the $\mathrm{OB}$ is accompanied by increased apoptosis (Fig. $5 B, C$ ). In particular, we found an increased number of cleaved Caspase 3 (Casp3)-positive apoptotic cells (Fig. 5B), as well as substantially increased levels of Casp3 in CMV-infected mice at W3 compared with CTL mice by immunoblot analysis of $\mathrm{OB}$ proteins (Fig. $5 G$, CMV vs CTL: Casp3: Mann-Whitney test, $U_{(6)}=0, p=0.0286$, $n=4$ mice per group).

The OB hosts a large population of resident microglial cells, the innate immune cells of the brain. OB microglial cells can be activated in response to pathological tissue changes, thus migrating to the site of injury, where they proliferate and acquire new functions including phagocytic activity and cytokine secretion (Lazarini et al., 2012, 2014; Hasegawa-Ishii et al., 2017). Recent studies have indicated a critical role of $\mathrm{OB}$ microglia in olfactory processing (Seo et al., 2016; Denizet et al., 2017; Reshef et al., 2017). We used Iba1, a marker of both unactivated and activated microglia, to visualize these immune cells in the OB of CMVinfected mice at W3 (Fig. 5D, middle, $E$ ). We found that congenital CMV infection activates OB microglia, as indicated by a change in morphology (Fig. $5 E$ ), an increased number of Iba1positive cells in all OB layers (Fig. $5 E$ ), and an increased expression of Iba1 and CD68, markers of activated microglia (Fig. 5C$E)$. Consistent with immunochemistry results, we found substantially increased levels of Iba1 and CD68 in CMV-infected mice at W3 compared with CTL mice by immunoblot analysis of
OB proteins (Fig. 5C, G, CMV vs CTL: Mann-Whitney test, Iba1: $U_{(6)}=0, p=0.0286$; CD68: $U_{(6)}=0, p=0.0286, n=4$ mice per group). Together, these findings reveal that congenital CMV infection causes fetal infection and leads to viral expression in the $\mathrm{OB}$ at W3 that is accompanied by increased apoptosis and inflammation.

\section{Congenital CMV infection alters $\mathrm{OB}$ neuron content}

The level of neuroinflammation and apoptosis in the $\mathrm{OB}$ of $\mathrm{CMV}$-infected mice at W3 prompted us to investigate whether infection and inflammation disrupted normal OB development and if a specific neuronal population was targeted. We observed neither global change in the bulbar architecture nor histologic changes in the lamination of the $\mathrm{OB}$ (Fig. 5D, middle). In particular, the mitral cell layer was similar in shape and size to those of CTL, suggesting no damage of these projection cells. Despite the presence of viral particles and microglial activation, OSN innervation to the $\mathrm{OB}$ of $\mathrm{CMV}$-infected mice was also similar to CTLs (Fig. 5D). Consistent with those observations made in the $\mathrm{OB}$, the OE was similar in shape and size to those of CTL (thickness of the OE, mean \pm SEM: CTL: $70.02 \pm 2.91 \mu \mathrm{m}$; CMV: $72.08 \pm 2.86$ $\mu \mathrm{m}, \mathrm{CMV}$ vs CTL: Mann-Whitney test, $U_{(11)}=18, p=0.701$, $n=6 \mathrm{CTL}, n=7 \mathrm{CMV})$. The number of OSNs also remained unchanged, suggesting no damage of sensory neurons (mean \pm SEM cell density of OMP-positive cells $\left(\times 10^{4}\right) / \mathrm{mm}^{3}$ : CTL: $40.44 \pm 4.20$; CMV: $37.61 \pm 3.67$, CMV vs CTL: Mann-Whitney test, $\left.U_{(10)}=14, p=0.631, n=5 \mathrm{CTL}, n=7 \mathrm{CMV}\right)$.

We subsequently assessed whether the increase in cell apoptosis induced by CMV infection could lead to substantial changes in neuronal subpopulations by visualizing CB-, calretinin (CR)-, and $\mathrm{TH}$-positive interneurons (Fig. 5F). CB- and CR-positive cells belong to the periglomerular neuron population that surrounds the glomeruli. $\mathrm{TH}$, the rate-limiting enzyme required for the synthesis of dopamine, is localized in periglomerular neurons and short axon cells. CB-, CR,- and TH-positive cells also contain GABA and glutamic acid decarboxylase, the rate-limiting enzyme for GABA biosynthesis. We found that CMV-infected mice showed a reduced population of $\mathrm{TH}$-positive cells in the $\mathrm{OB}$ glomeruli at W3 after birth (Fig. 5F,H, CMV vs CTL: MannWhitney test, $U_{(10)}=4, p=0.026 ; n=6$ mice per group). We also observed a decreased population of $\mathrm{CB}$-positive cells in the glomeruli of these infected mice at W3 (Fig. $5 F, H$, CMV vs CTL: Mann-Whitney test, $U_{(9)}=0, p=0.0043 ; n=5 \mathrm{CTL}, n=6$ $\mathrm{CMV})$. In contrast, the cell density of CR-positive cells was similar to CTL mice, indicating a higher vulnerability for bulbar dopaminergic and CB- expressing neurons to CMV infection (Fig. 5F, H, CMV vs CTL: Mann-Whitney test, $U_{(6)}=6, p=$ $0.6571 ; n=4$ mice per group). The depletion of TH- and CBpositive cells observed in infected animals might reflect a direct viral tropism for this neuronal category or result from neuroinflammation-induced cell death and/or reduced neurogenesis. It is important to note that the neurogenic SVZ provides the postnatal $\mathrm{OB}$ with interneurons throughout its lifespan in rodents. This area gives rise to thousands of neuroblasts per day that migrate via the RMS toward the $\mathrm{OB}$, where they functionally integrate with preexisting neuronal circuits and differentiate mostly into granule cells and periglomerular interneurons (Fig. $5 A$; Lledo et al., 2006). Interestingly, we found a decrease in cell proliferation in the SVZ at W3 (Fig. $5 D, H$, CMV vs CTL male mice: Mann-Whitney test, $U_{(9)}=0, p=0.0043 ; n=6$ CTL, $n=$ $5 \mathrm{CMV}$ ), supporting the hypothesis that CMV might affect SVZ neural progenitor cell proliferation and thus postnatal neurogen- 


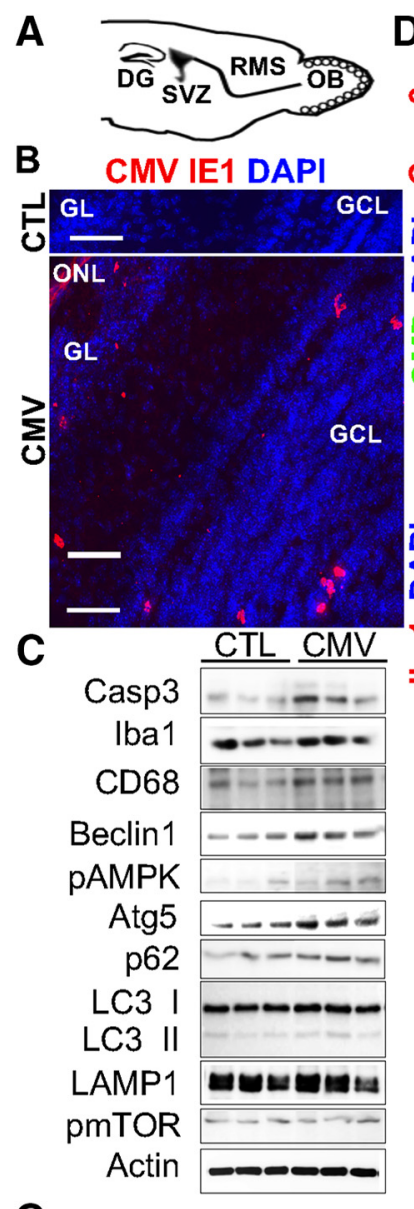

G

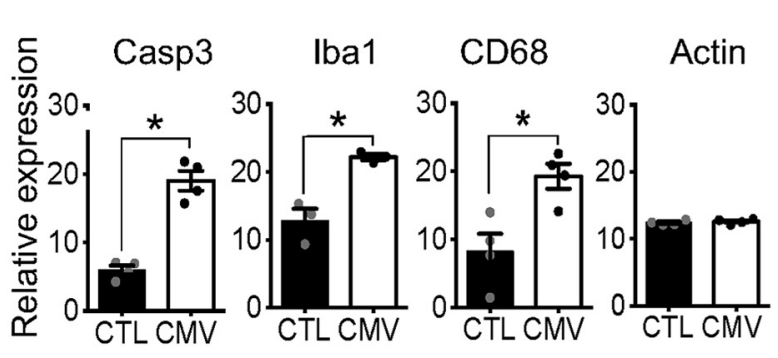

D CTL CMV E

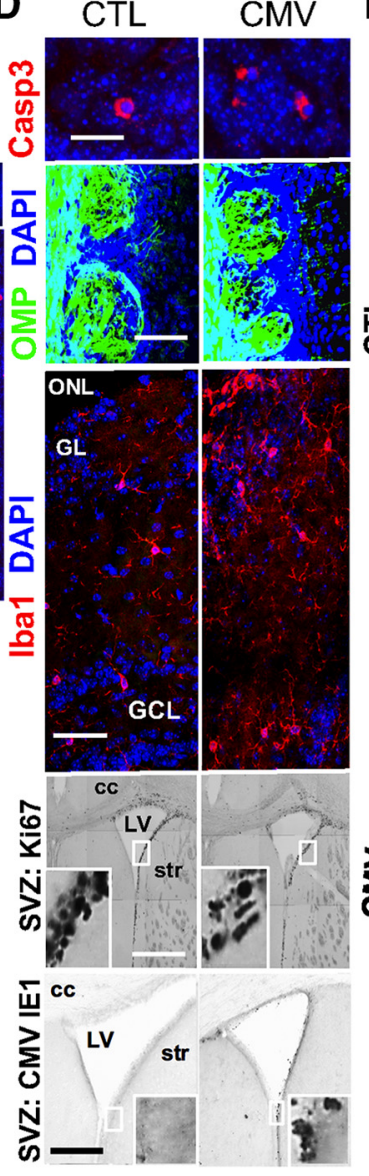

E lba1 CD68 DAPI

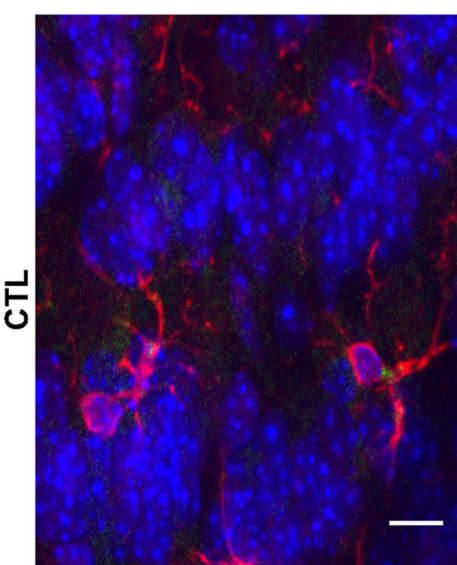

F
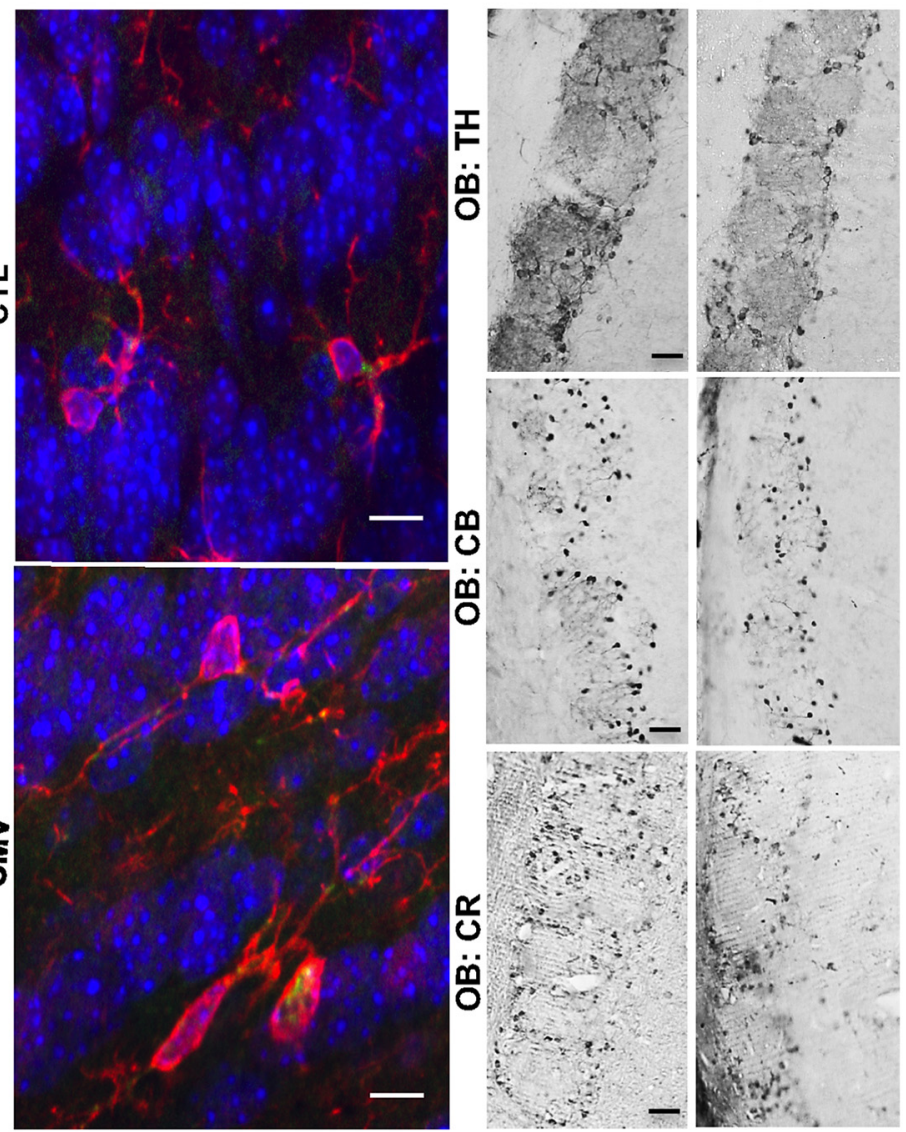

H

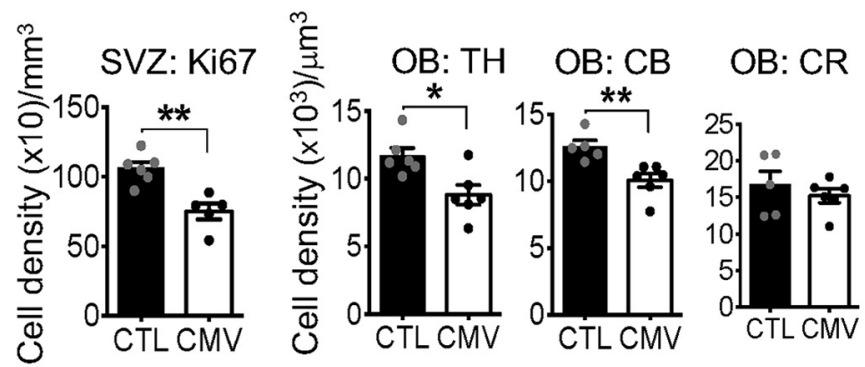

I

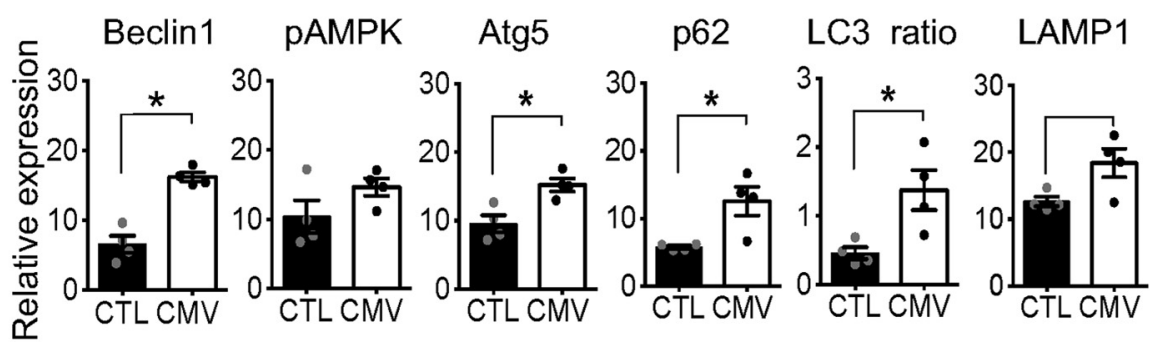

J

Glomerulus area

RMS/GCL
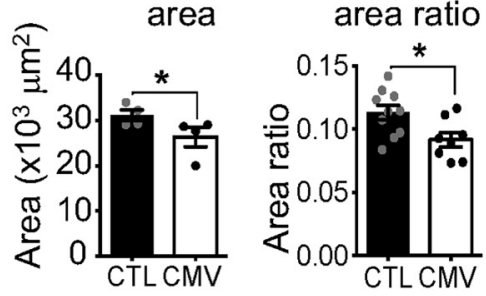

Figure 5. Impact of CMV congenital infection on the postnatal olfactory system at W3. $A$, Sagittal section of a murine brain showing the neurogenic dentate gyrus (DG) of the hippocampus, the neurogenic SVZ, the RMS, and the OB. Neuroblasts born in the neonatal and postnatal SVZ migrate via the RMS until the OB, where they differentiate into GCL or GL interneurons. $\boldsymbol{B}, \boldsymbol{D}-\boldsymbol{F}$, Representative staining of coronal SVZ ( $\boldsymbol{D}$, bottom) and OB slices with DAPI ( $\boldsymbol{B}, \boldsymbol{D}, \boldsymbol{E})$ murine CMV IE1 (B, D, bottom), cleaved caspase 3 (Casp3, $\boldsymbol{D}$, top), 0MP expressed by 0SN (D, middle), lba ( $\boldsymbol{D}$, middle; $\boldsymbol{E})$, CD68 expressed by activated microglia and macrophages $(\boldsymbol{E}), \mathrm{Ki} 67(\boldsymbol{D}), \mathrm{TH}(\boldsymbol{F}), \mathrm{CB}(\boldsymbol{F})$, and $(\mathrm{R}(\boldsymbol{F})$, antibodies showing $\mathrm{CMV}+$, apoptotic Casp3 +, 0SN, macrophages, microglia, Ki67+ neural progenitor cells, TH+, CB + and CR + cells in CTL and congenital CMV-infected mice at W3 after birth. C, G-I, Screening of the OB proteins from congenital CMV-infected mice at W3 for autophagy induction $(\boldsymbol{C}, \boldsymbol{I})$, cell apoptosis $(\boldsymbol{C}, \boldsymbol{G})$, and microglial reaction $(\boldsymbol{C}, \boldsymbol{G})$. Lysates were extracted from the OB of $(T L$ and congenital $\mathbf{C M V}$-infected mice at W3 and analyzed by immunoblot $(\boldsymbol{C})$ using antibodies to detect Casp3, Iba1, CD68, Beclin1, phospho-AMPK, Atg5, p62, LC3 I/II, LAMP, phospho-mTOR, and actin (three mice each). The levels of Casp3, lba, CD68, Beclin1, pAMPK, Atg5, p62, LC3 II/ LC3 I, LAMP, pmTOR, and actin were quantified (G,I) by band intensity with Fiji software. $\boldsymbol{H}, \mathbf{J}, \mathrm{Ki} 67+$, TH + , CB + , and CR + cell densities in the SVZ, GL, glomerulus (glom), and GCL at W3 following congenital CMV inoculation. All mice are W3-old males injected at E13 with PBS (CTL) or CMV. For immunoblot analysis $(\boldsymbol{G}, \boldsymbol{I}), n=4$ mice per group. For cell density analysis ( $\boldsymbol{H})$ and area ratio $(J), n=4-6$ mice per group. For glom size $(J), n=409$ glom from 4 CTL, $n=352$ glom from 4 CMV. Results are shown as mean \pm SEM. $p$-values were calculated by Mann-Whitney test. ${ }^{*} p<0.05$, ${ }^{* *} p<0.01$. Scale bars: $100 \mu \mathrm{m}$ in $\boldsymbol{D}$, bottom; $50 \mu \mathrm{m}$ in $\boldsymbol{B}, \boldsymbol{D}$, middle, and $\boldsymbol{F} ; 25 \mu \mathrm{m}$ in $\boldsymbol{D}$, bottom; and $5 \mu \mathrm{m}$ in $\boldsymbol{D}$, top, and $\boldsymbol{E}$. 
A

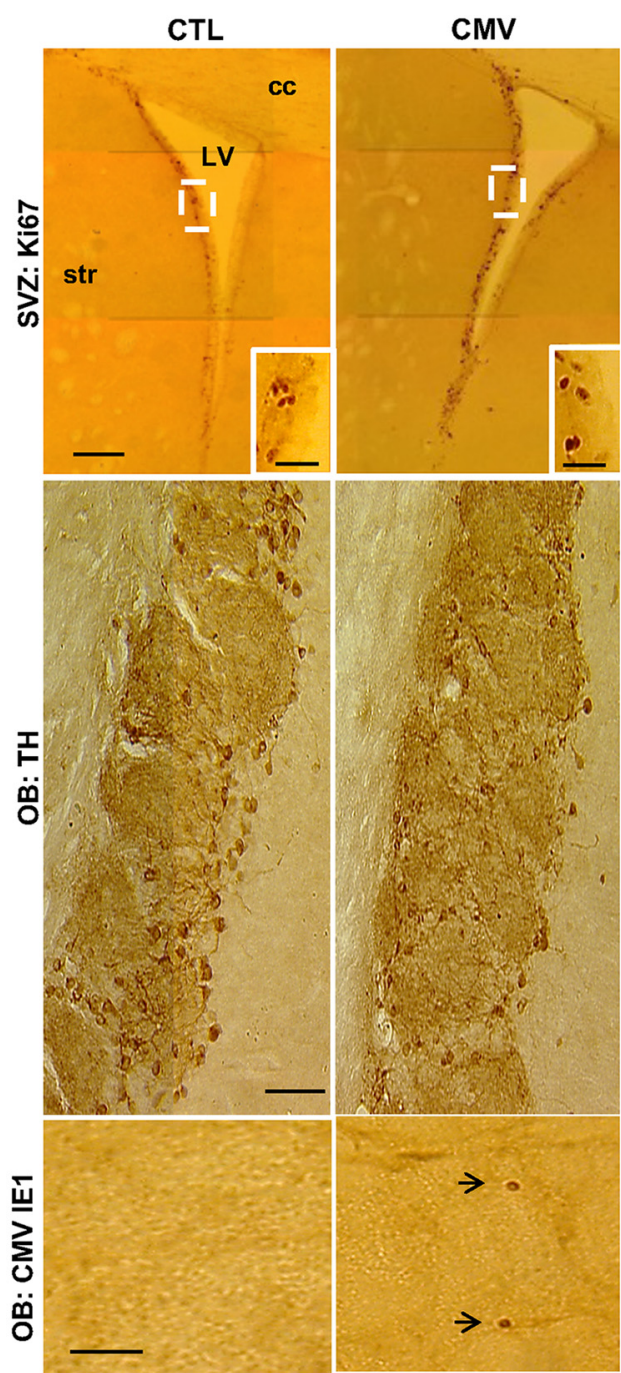

B

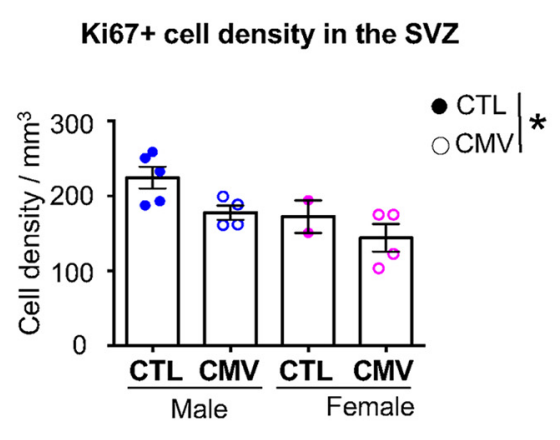

\section{TH + cell density in the $O B$}
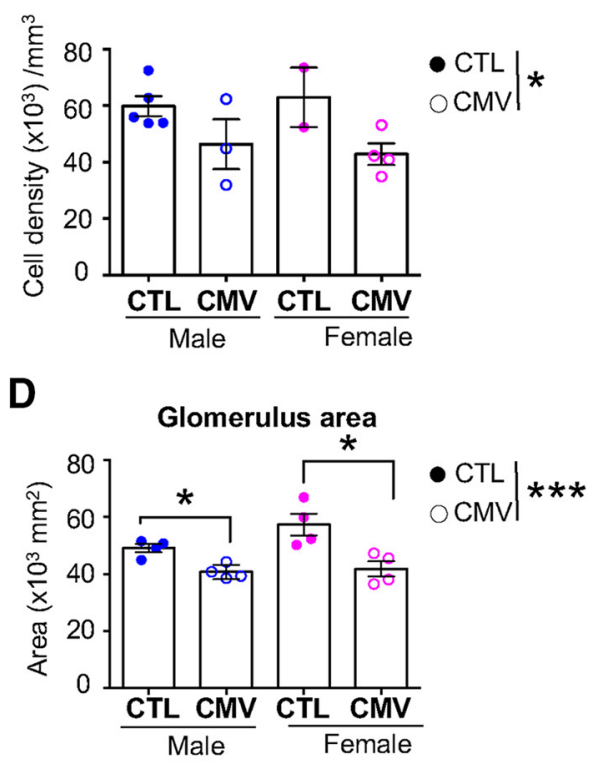

Figure 6. Long-lasting impact of CMV congenital infection on the adult OB.A, Representative staining of coronal SVZ (top) and OB (middle, bottom) slices with Ki67 (top), $\mathrm{TH}$ (middle) and murine CMV IE1 (bottom). $\boldsymbol{B}-\boldsymbol{D}$, Ki67 + cell densities in the SVZ (B), TH + cell densities in the GL $(\boldsymbol{C})$, and glomerulus size ( $\boldsymbol{D})$ at W16 after birth following congenital CMV inoculation. For cell density analysis, $n=5$ male CTL, $n=2$ female CTL, $n=4$ male CMV, $n=4$ female CMV. For glomerulus size, $n=212$ glomeruli from 2 CTL females, $n=409$ glomeruli from 4 CMV females, $n=499$ glomeruli from 4 CTL males, $n=262$ glomeruli from 4 CMV males. Results in $\boldsymbol{D}$ are shown as mean \pm SEM. $p$-values were calculated by Mann-Whitney test. ${ }^{*} p<0.05$, ${ }^{* * *} p<0.001$. Cc, Corpus callosum; LV, lateral ventricle; str, striatum. Scale bars: $100 \mu \mathrm{m}$ in $A$, top; $50 \mu \mathrm{m}$ in $A$, middle and bottom).

esis in mice (Mutnal et al., 2011). However, further experiments are needed to characterize the precise populations that are lost in the SVZ, the fate of the proliferating survivor cells, and the impact on neuronal progenitor migration and survival.

Finally, we assessed whether the decrease in the amount of interneurons could change the $\mathrm{OB}$ size. Our anatomical investigations demonstrated that CMV OB neuroinvasion was accompanied by differential changes in the relative size of the different layers of the $\mathrm{OB}$ at W3, including the RMS, GL, and GCL (Fig. $5 J$ ), which is composed of GABAergic interneurons that regulate the neuronal activity of output $\mathrm{OB}$ neurons. To address the viral impact on the $\mathrm{OB}$ innervation from the periphery, we measured the glomerulus area using OMP staining. Congenital CMV infection decreased the mean size of glomeruli in infected male animals at W3 (Figs. 5J, 6D; glomerulus area: CMV vs CTL; Mann-Whitney test, $U_{(6)}=0, p=0.0286, n=4$ CTL (409 glomeruli), $n=4 \mathrm{CMV}$ (304 glomeruli). Additionally, the RMS/ GCL area ratio is decreased in infected animals (Fig. 5J, CMV vs CTL; Mann-Whitney test, $U_{(16)}=14, p=0.025, n=10 \mathrm{CTL}$, $n=8 \mathrm{CMV})$. We found a correlation between RMS and GCL sizes in CTL OBs (Spearman $r=0.782, p=0.011, n=11 \mathrm{CTL}$ ), but not in CMV-infected animals (Spearman's $r=0.333, p=$ $0.428, n=8 \mathrm{CMV}$ ), suggesting that congenital CMV infection differentially alters the development of these OB cell layers, thus leading to disproportionate $\mathrm{OB}$ structure. A slight difference between CTL and CMV was found for either body weight (mean \pm SEM in CTL: $18.53 \pm 0.50 \mathrm{~g}$; in CMV: $16.94 \pm 0.54$ g; MannWhitney test, $U_{(46)}=160.5, p=0.0257, n=17$ CTL, $n=31$ CMV or brain weight (mean \pm SEM in CTL: $500.8 \pm 14.42 \mathrm{mg}$; in CMV: $464.4 \pm 7.934 \mathrm{mg}$, Mann-Whitney test, $U_{(46)}=172, p=$ $0.0490, n=17$ CTL, $n=31$ CMV). However, no correlation was found between body and brain weight for each group (data not shown). Finally, no correlation was found between RMS and GL, GCL and GL, GL and the mouse body weight, or brain weight and body weight at W3 in the both groups (data not shown). Therefore, CMV-infected preweaning male mice exhibit OB proportionate and disproportionate developmental abnormalities, neuroinflammation, and fewer bulbar interneuron cells that together might contribute to an olfactory deficit. 


\section{Congenital CMV infection increases hallmarks of autophagy in preweaning mice}

Given the high degree of bulbar apoptosis and neuroinflammation induced by congenital CMV infection, we investigated the impact of this virus on the levels of several protein markers of autophagy in the $\mathrm{OB}$ at W3 (Fig. 5C,I). Beclin1 is a key autophagy-related protein that participates in the induction and formation of autophagosomes. Microtubule-associated protein 1 light chain 3 (LC3) is specifically associated with autophagosomal membranes and plays a critical role during the expansion step of autophagosome formation. LC3 has two forms, nonlipidated (LC3 I) and lipidated (LC3 II). Initiation of autophagy is characterized by the formation of LC3 II via conjugation of LC3I to phosphatidyletholamine. This conjugation needs the activation of autophagy related 5 protein (Atg5). P62 is specially degraded in autolysosomes and thus is widely used to monitor autophagic flux. Lysosomal-associated membrane protein 1 (LAMP1) is a glycoprotein responsible for maintaining lysosomal integrity. However, measuring the expression of Beclin1, LC3I, LC3 II, Atg5, and LAMP1 provides a good indication of the extent of autophagy (Mizushima and Levine, 2010).

Western blot analysis of OB proteins from CMV-infected mice showed increased autophagic activity, including increased levels of Beclin1 and Atg5 (Fig. 5C,I, CMV vs CTL: Mann-Whitney test, Beclin1: $U_{(6)}=0, p=0.0286$; Atg5: $U_{(6)}=$ $0, p=0.0286$ ). The levels of autophagosome formation are particularly elevated, as demonstrated by our evidence for a fourfold increase in Beclin1 expression (Fig. 5I). We found a trend for enhanced expression of LAMP1 (Fig. 5C,I, CMV vs CTL: MannWhitney test, $\left.U_{(6)}=1, p=0.0571\right)$. The dramatic increase in Beclin1 expression prompted us to investigate whether the pAMP-activated protein kinase (pAMPK)-mammalian target of rapamycin (mTOR) signaling pathway is involved. In this metabolic signaling pathway, situated upstream of the autophagic pathway, pAMPK activation upregulates the cellular energy needed for autophagy induction and inhibits mTOR, leading to beclinl engagement (Mizushima and Levine, 2010). We found no significant changes in the pAMPK and pTOR expression (Fig. 5C,I, CMV vs CTL: Mann-Whitney test, pAMPK: $U_{(6)}=4, p=$ 0.3429; PTOR: $U_{(6)}=3, p=0.2000$ ), suggesting no involvement of this metabolic signaling pathway in our viral model.

Finally, we investigated the modulation of p62 and LC3 autophagic markers involved in the autophagic flux. We found a twofold increase in p62 expression that indicates an increase in the autophagosome clearance and thus in the autophagic flux (Fig. $5 C, I$, CMV vs CTL: Mann-Whitney test, $U_{(6)}=0, p=$ 0.0286). Western blot data also reveal an increase in the LC3II/I ratio, further suggesting that congenital $\mathrm{CMV}$ increases autophagic flux (Fig. 5 C, I, CMV vs CTL: Mann-Whitney test, $U_{(6)}$ $=0, p=0.0286)$. Altogether, our data indicate that congenital CMV infection results in the upregulation of autophagy at W3 that might support neuroinflammation and cell apoptosis.

\section{Long-lasting effect of congenital CMV infection on the olfactory system}

Given the structural abnormalities of both the SVZ and OB at W3 and the long-lasting olfactory deficits induced by congenital CMV infection, we assessed the long-term consequences for the olfactory system in adult male and female mice at W16 (Fig. 6). We found a decrease in cell proliferation in the SVZ at W16 after birth (Fig. 6A, $B$, CMV vs CTL: LC3 ratio: Mann-Whitney test, $\left.U_{(13)}=10, p=0.0401, n=8 \mathrm{CTL}, n=7 \mathrm{CMV}\right)$, supporting the view that CMV congenital infection results in a long-term reduc- tion of postnatal cell proliferation in this neurogenic zone. No difference was found between males and females in either the CTL or CMV group (data not shown). Anatomical investigations of the $\mathrm{OB}$ of $\mathrm{CMV}$-infected mice reveal viral expression in all layers of this structure at W16 after birth (Fig. 6A), but no proliferation or activation of local microglia (data not shown). These findings indicate that, at least in our animal model, CMV placental infection leads to long-term viral infection of the embryos and transient neuroinflammation in the OB. No difference was found for either the body or the brain weight between CTL and CMV (data not shown).

Moreover, we found that CMV-infected mice showed a persistent reduction in the population of dopaminergic $\mathrm{TH}+$ cells in the OB glomeruli at W16 (Fig. 6A, C; CMV vs CTL: Mann-Whitney test, $U_{(12)}=5, p=0.0111, n=7$ CTL, $n=7$ CMV). No difference was found between males and females in either the CTL or CMV group (data not shown). The cell densities of the two other glomerular populations, CB- and CR-positive cells, are similar to CTL mice, indicating a recovery for the CB-positive cell population compared with the $\mathrm{W} 3$ earlier time point. This recovery might probably result from ongoing adult neurogenesis. The reduction of glomerular TH-positive cell number in infected animals is similar in magnitude for the two time points, W3 and W6, indicating a higher vulnerability for bulbar dopaminergic neurons to CMV infection. Their loss in this context is accompanied by a reduced mean size of glomeruli in infected animals (Fig. $6 D$, glomerulus area: CMV vs CTL; Mann-Whitney test, all mice: $U_{(14)}=2, p=0.0006, n=8$ mice per group; males: $U_{(10)}=0, p=$ 0.0286, $n=4$ male mice per group; females: $U_{(10)}=0, p=$ $0.0286, n=4$ females per group). No difference was found between males and females in either the CTL or CMV group (data not shown). Conversely, the difference in the GCL size that we observed at W3 did not persist later at W16, suggesting a recovery for the GCL interneuron population likely due to the ongoing adult neurogenesis (data not shown). Thus, congenital CMV infection leads to long-term alteration of the OB structure, compromised cell proliferation in the SVZ, and fewer bulbar dopaminergic cells that together might contribute to the olfactory deficit that we report here in infected mice.

\section{Discussion}

We identify olfactory deficit as early sensory impairment much before hearing deterioration, making hyposmia an early functional consequence of congenital CMV infection in mice. We show, for the first time, that placental CMV inoculation of embryos results in viral infection of the $\mathrm{OB}$, transient activation of microglial cells, disproportionate $\mathrm{OB}$ cell layers, and alteration of the OB interneuron development and impairment of the sense of smell long before auditory deficits emerge. These findings confirm and extend previous work showing CMV-induced OB lesions in human fetuses (Teissier et al., 2014) and the importance of $\mathrm{OB}$ interneurons in processing properly olfactory information (Kobayakawa et al., 2007; Khodosevich et al., 2013; Lazarini et al., 2014; Grelat et al., 2018).

In the present study, we used in utero intraplacental inoculation of murine CMV as a model to study CMV infection during human pregnancy. Previous studies demonstrate that this murine model recapitulates many features of congenital human CMV infection, such as altered hindbrain morphogenesis, robust CNS neuroinflammation, infection of the inner ear, and lesions responsible for deafness (Li et al., 2000; Koontz et al., 2008; Kosmac et al., 2013; Sakao-Suzuki et al., 2014; Bradford et al., 2015). $\mathrm{CMV}$ is species specific, but the murine CMV genome is highly 
similar to that of the human CMV (Rawlinson et al., 1996). It is important to note that susceptibility to CMV infection is age dependent and host maturation is associated with decreased virus replication and less severe neurological outcomes in both humans and mice (Tsutsui, 2009; Muller et al., 2010). Indeed, in humans and rodent models, vulnerability to neurological complications depends on both the maturation of the immune system and a decreased susceptibility of maturing neurons to infection and cell death (Oliver et al., 1997; Schultz et al., 2015; Almishaal et al., 2017). Therefore, we chose an in utero infection model with the well characterized murine CMV Smith strain, which is known to replicate in the brain and induce neuropathology following transplacental inoculation (Li et al., 2000). In vivo studies of congenital human CMV infection are limited due to the strict host specificity of CMV. In contrast to human CMV, murine CMV rarely crosses the placenta, except when it is directly inoculated in this tissue. The virus then disseminates to other tissues of the embryo including liver, lung, salivary glands, and brain, where infection results in widespread encephalitis (Li and Tsutsui, 2000; Juanjuan et al., 2011; Sakao-Suzuki et al., 2014). Here. we provide experimental evidence that $\mathrm{CMV}$ can infect the $\mathrm{OB}$ following in utero transplacental inoculation, consistent with previous reports on rodent models and our observations in human fetuses (Cekinović et al., 2008; Teissier et al., 2011, 2014). Moreover, we show that this $\mathrm{OB}$ viral expression persists for a long time because viral expression was detected in OB cells at both W3 and W16 after birth.

We also report for the first time that the $\mathrm{OB}$ viral infection is accompanied by increased autophagy. Autophagy is a highly conserved process involved in the turnover of damaged organelles and long-lived proteins in both physiological and pathological conditions (Nakatogawa et al., 2009). This degradative pathway involves the sequestration of cytoplasmic constituents within double-membrane-bound compartments called autophagosomes and delivery of the contents to lysosomes for degradation and recycling. Recent studies have shown important roles for autophagy genes in cell apoptosis, neuroinflammation, and neurogenesis (Maiuri et al., 2007; Cloëtta et al., 2013; Deretic et al., 2013). Autophagy is also frequently seen as a mechanism to degrade microorganisms including viruses that invade intracellularly (Levine et al., 2011). Consistent with a link between autophagy and human CMV infection (Chaumorcel et al., 2008; McFarlane et al., 2011), we show increased autophagic activity including increased levels of essential autophagy components such as Beclin1, Atg5, and p62.

We found an increase in cell apoptosis in infected OB at W3, consistent with previous studies (Kosugi et al., 1998). The upregulated autophagy might support $\mathrm{OB}$ apoptosis because overactive autophagy leads to a high turnover rate of organelles and proteins, thus promoting cell death (Maiuri et al., 2007). Microglial activation in the brain after CMV infection was recorded in several studies, but the autophagy stimulus for this effect was not investigated (Ibanez et al., 1991; Koontz et al., 2008; Cloarec et al., 2016; Brizić et al., 2017). Consistent with a link between autophagy and neuroinflammation (Deretic et al., 2013), our findings reveal activation of both autophagy and microglial cells in the infected $\mathrm{OB}$ at W3. Interestingly, autophagy activation did not persist at later time points; nor did neuroinflammation, suggesting an immune control of the virus at the adult stage (data not shown). Further experiments on the time course of OB viral replication, autophagy, and neuroinflammation should shed light on the viral mechanisms of neuronal loss in this model.
The dramatic loss of smell induced by congenital CMV infection might be due to direct neuron damage into the olfactory system or be an indirect defect in neuron development. Because the onset of olfactory loss presumably occurs secondary to the viral insult, a direct damage of OSNs is likely. For instance, a direct in utero infection of OSNs followed by viral propagation to the $\mathrm{OB}$ via $\mathrm{OSN}$ axons might lead to infection of the $\mathrm{OB}$ tissue. In the present study, we show that, despite the presence of viral particles in the GL, the cell density of OMP-positive OSNs in the sensory organ and OSN innervation to the OB of CMV-infected mice are similar to CTLs. This finding supports previous observations that peripheral infection with neurotropic viruses such as Bunyavirus leads to specific brain neuroinvasion via OB capillaries, but not through OSN axons (Winkler et al., 2015). Nevertheless, we cannot exclude the possibility that in utero infected OSNs spread the virus to the brain. OSNs have the unique characteristic to undergo continuous replacement throughout life (Graziadei and Monti Graziadei, 1983). This ability, observed in all vertebrates, might allow a complete recovery of OSN inputs following viral insult in the neonate.

Although OSN inputs and mitral cell population seem to be spared by CMV, we found that congenital viral infection differentially affect the cell layers and neuron populations of the OB. The reduced $\mathrm{TH}$ expression, $\mathrm{CB}$ expression, and maybe reduced glomerulus size are consistent with significant reductions in physiological OSN input to the bulb, even if the OSN projection morphology is unchanged (Stone et al., 1990; Philpot et al., 1997; Kass et al., 2013). It is possible that the increased apoptosis in the $\mathrm{OB}$ and the reduced neurogenesis in the SVZ may affect the $\mathrm{OB}$ cell number, thus providing a mechanism for olfactory loss. CBand $\mathrm{TH}$-positive cells are primarily inhibitory and modulate neuronal function. Their cell number reduction could underlie olfactory changes. Later, at W16, only the depletion of the dopaminergic cell population in OB glomeruli persisted in our model, suggesting a higher vulnerability of these cells. Dopaminergic neurons play a key role in olfactory detection of social and nonsocial odorants and their damage leads to a dramatic olfactory deficit (Lazarini et al., 2014). Because the peak of dopaminergic cell recruitment in the rodent $\mathrm{OB}$ occurs in early postnatal life (De Marchis et al., 2007, during maximum brain growth (Semple et al., 2013), it is probable that bulbar dopaminergic neurons are affected during this time window by congenital CMV infection.

Our study provides the first evidence that congenital CMV can impair both hearing and olfaction. A recent epidemiological study reported a remarkable correlation between hearing loss and olfactory dysfunction in the Korean population after adjustment for age and sex, but did not study infection as an influential factor (Park et al., 2017). Other studies in rodents have shown neuroinvasion in the olfactory system after CMV infection, but did not assess olfactory behavior (Farrell et al., 2016). Early detection of olfactory deficits might be relevant to anticipate reduced food intake and loss of social olfactory cues important to maintain a strong parent-infant bound (Engen and Lipsitt, 1965; Lemasson et al., 2005; Harding et al., 2017). Further, we reveal that smell alteration precedes hearing deterioration at least in the mouse model. In congenital human CMV infection, hearing loss may occur several years after birth and can be progressive. Identification of children susceptible to hearing impairment is of major interest because early treatment and use of a hearing aid may minimize the impact of this deficit on cognitive development. Despite differences in neurogenesis and sensory development between human and mouse (Lui et al., 2014; Clark-Gambelunghe and Clark, 2015), our preclinical findings provide experimental 
support for clinical trials in congenital CMV infection. Assessing olfaction could lead to novel strategies to monitor this infection, including long-term neurological outcomes. Future studies of structural changes in the $\mathrm{OB}$ circuit and the functionality of interneuron populations could yield relevant translational results for follow-up of these infections.

\section{References}

Almishaal AA, Mathur PD, Hillas E, Chen L, Zhang A, Yang J, Wang Y, Yokoyama WM, Firpo MA, Park AH (2017) Natural killer cells attenuate cytomegalovirus-induced hearing loss in mice. PLoS Pathog 13: e1006599. CrossRef Medline

Alonso M, Lepousez G, Sebastien W, Bardy C, Gabellec MM, Torquet N, Lledo PM (2012) Activation of adult-born neurons facilitates learning and memory. Nat Neurosci 15:897-904. CrossRef Medline

Bradford RD, Yoo YG, Golemac M, Pugel EP, Jonjic S, Britt WJ (2015) Murine CMV-induced hearing loss is associated with inner ear inflammation and loss of spiral ganglia neurons. PLoS Pathog 11:e1004774. CrossRef Medline

Bradley RM, Mistretta CM (1975) Fetal sensory receptors. Physiol Rev 55: 352-382. Medline

Branchi I, Santucci D, Vitale A, Alleva E (1998) Ultrasonic vocalizations by infant laboratory mice: a preliminary spectrographic characterization under different conditions. Dev Psychobiol 33:249-256. CrossRef Medline

Brizić I, Hiršl L, Britt WJ, Krmpotić A, Jonjić S (2017) Immune responses to congenital cytomegalovirus infection. Microbes Infect. Advance online publication. Retrieved December 26, 2017. doi: 10.1016/ j.micinf.2017.12.010.

Cekinović D, Golemac M, Pugel EP, Tomac J, Cicin-Sain L, Slavuljica I, Bradford R, Misch S, Winkler TH, Mach M, Britt WJ, Jonjić S (2008) Passive immunization reduces murine cytomegalovirus-induced brain pathology in newborn mice. J Virol 82:12172-12180. CrossRef Medline

Chaumorcel M, Souquère S, Pierron G, Codogno P, Esclatine A (2008) Human cytomegalovirus controls a new autophagy-dependent cellular antiviral defense mechanism. Autophagy 4:46-53. CrossRef Medline

Clark-Gambelunghe MB, Clark DA (2015) Sensory development. Pediatr Clin North Am 62:367-384. CrossRef Medline

Cloarec R, Bauer S, Luche H, Buhler E, Pallesi-Pocachard E, Salmi M, Courtens S, Massacrier A, Grenot P, Teissier N, Watrin F, Schaller F, AdleBiassette H, Gressens P, Malissen M, Stamminger T, Streblow DN, Bruneau N, Szepetowski P (2016) Cytomegalovirus infection of the rat developing brain in utero prominently targets immune cells and promotes early microglial activation. PLoS One 11:e0160176. CrossRef Medline

Cloëtta D, Thomanetz V, Baranek C, Lustenberger RM, Lin S, Oliveri F, Atanasoski S, Rüegg MA (2013) Inactivation of mTORC1 in the developing brain causes microcephaly and affects gliogenesis. J Neurosci 33: 7799-7810. CrossRef Medline

Coyne CB, Lazear HM (2016) Zika virus: reigniting the TORCH. Nat Rev Microbiol 14:707-715. CrossRef Medline

de Chaumont F, Dallongeville S, Chenouard N, Hervé N, Pop S, Provoost T, Meas-Yedid V, Pankajakshan P, Lecomte T, Le Montagner Y, Lagache T, Dufour A, Olivo-Marin JC (2012) Icy: an open bioimage informatics platform for extended reproducible research. Nat Methods 9:690-966. CrossRef Medline

De Marchis S, Bovetti S, Carletti B, Hsieh YC, Garzotto D, Peretto P, Fasolo A, Puche AC, Rossi F (2007) Generation of distinct types of periglomerular olfactory bulb interneurons during development and in adult mice: implication for intrinsic properties of the subventricular zone progenitor population. J Neurosci 27:657-664. CrossRef Medline

Denizet M, Cotter L, Lledo PM, Lazarini F (2017) Sensory deprivation increases phagocytosis of adult-born neurons by activated microglia in the olfactory bulb. Brain Behav Immun 60:38-43. CrossRef Medline

Deretic V, Saitoh T, Akira S (2013) Autophagy in infection, inflammation and immunity. Nat Rev Immunol 13:722-737. CrossRef Medline

Engen Y, Lipsitt LP (1965) Decrement and recovery of responses to olfactory stimuli in the human neonate. J Comp Physiol Psychol 59:312-316. CrossRef Medline

Farrell HE, Lawler C, Tan CS, MacDonald K, Bruce K, Mach M, DavisPoynter N, Stevenson PG (2016) Murine cytomegalovirus exploits olfaction to enter new hosts. MBio 7:e00251-316. CrossRef Medline

Fornara C, Cassaniti I, Zavattoni M, Furione M, Adzasehoun KMG, De Sil- vestri A, Comolli G, Baldanti F (2017) Human cytomegalovirus-specific memory CD4+ T-cell response and its correlation with virus transmission to the fetus in pregnant women with primary infection. Clin Infect Dis 65:1659-1665. CrossRef Medline

Forner G, Abate D, Mengoli C, Palù G, Gussetti N (2015) High cytomegalovirus (CMV) DNAemia predicts CMV sequelae in asymptomatic congenitally infected newborns born to women with primary infection during pregnancy. J Infect Dis 212:67-71. CrossRef Medline

Graziadei PP, Monti Graziadei AG (1983) Regeneration in the olfactory system of vertebrates. Am J Otolaryngol 4:228-233. CrossRef Medline

Grelat A, Benoit L, Wagner S, Moigneu C, Lledo PM, Alonso M (2018) Adult-born neurons boost odor-reward association. Proc Natl Acad Sci U S A 115:2514-2519. CrossRef Medline

Han GP, Li L, Kosugi I, Kawasaki H, Tsuchida T, Miura K, Tsutsui Y (2007) Enhancement of susceptibility of adult mouse brain to cytomegalovirus infection by infusion of epidermal growth factor. J Neurosci Res 85:29812990. CrossRef Medline

Harding JE, Cormack BE, Alexander T, Alsweiler JM, Bloomfield FH (2017) Advances in nutrition of the newborn infant. Lancet 389:1660-1668. CrossRef Medline

Hasegawa-Ishii S, Shimada A, Imamura F (2017) Lipopolysaccharideinitiated persistent rhinitis causes gliosis and synaptic loss in the olfactory bulb. Sci Rep 7:11605. CrossRef Medline

Ibanez CE, Schrier R, Ghazal P, Wiley C, Nelson JA (1991) Human cytomegalovirus productively infects primary differentiated macrophages. J Virol 65:6581-6588. Medline

Jackson JW, Sparer T (2018) There is always another way! Cytomegalovirus' multifaceted dissemination schemes. Viruses 10:E383. CrossRef Medline

Juanjuan C, Yan F, Li C, Haizhi L, Ling W, Xinrong W, Juan X, Tao L, Zongzhi Y, Suhua C (2011) Murine model for congenital CMV infection and hearing impairment. Virol J 8:70. CrossRef Medline

Kass MD, Pottackal J, Turkel DJ, McGann JP (2013) Changes in the neural representation of odorants after olfactory deprivation in the adult mouse olfactory bulb. Chem Senses 38:77-89. CrossRef Medline

Kennedy WP, Lewis CP, Stow J, Sobol SE (2016) A critical period in postnatal neuroplasticity of olfaction: a pediatric tracheostomy model. JAMA Otolaryngol Head Neck Surg 142:127-131. CrossRef Medline

Khodosevich K, Lazarini F, von Engelhardt J, Kaneko H, Lledo PM, Monyer H (2013) Connective tissue growth factor regulates interneuron survival and information processing in the olfactory bulb. Neuron 79:1136-1151. CrossRef Medline

Kobayakawa K, Kobayakawa R, Matsumoto H, Oka Y, Imai T, Ikawa M, Okabe M, Ikeda T, Itohara S, Kikusui T, Mori K, Sakano H (2007) Innate versus learned odour processing in the mouse olfactory bulb. Nature 450:503-508. CrossRef Medline

Koontz T, Bralic M, Tomac J, Pernjak-Pugel E, Bantug G, Jonjic S, Britt WJ (2008) Altered development of the brain after focal herpesvirus infection of the central nervous system. J Exp Med 205:423-435. CrossRef Medline

Kosmac K, Bantug GR, Pugel EP, Cekinovic D, Jonjic S, Britt WJ (2013) Glucocorticoid treatment of MCMV infected newborn mice attenuates CNS inflammation and limits deficits in cerebellar development. PLoS Pathog 9:e1003200. CrossRef Medline

Kosugi I, Shinmura Y, Li RY, Aiba-Masago S, Baba S, Miura K, Tsutsui Y (1998) Murine cytomegalovirus induces apoptosis in non-infected cells of the developing mouse brain and blocks apoptosis in primary neuronal culture. Acta Neuropathol 96:239-247. CrossRef Medline

Lazarini F, Gabellec MM, Torquet N, Lledo PM (2012) Early activation of microglia triggers long-lasting impairment of adult neurogenesis in the olfactory bulb. J Neurosci 32:3652-3664. CrossRef Medline

Lazarini F, Gabellec MM, Moigneu C, de Chaumont F, Olivo-Marin JC, Lledo PM (2014) Adult neurogenesis restores dopaminergic neuronal loss in the olfactory bulb. J Neurosci 34:14430-14442. CrossRef Medline

Lemasson M, Delbé C, Gheusi G, Vincent JD, Lledo PM (2005) Use of ultrasonic vocalizations to assess olfactory detection in mouse pups treated with 3-methylindole. Behav Processes 68:13-23. CrossRef Medline

Levine B, Mizushima N, Virgin HW (2011) Autophagy in immunity and inflammation. Nature 469:323-335. CrossRef Medline

Li RY, Tsutsui Y (2000) Growth retardation and microcephaly induced in mice by placental infection with murine cytomegalovirus. Teratology 62: 79-85. CrossRef Medline

Lledo PM, Alonso M, Grubb MS (2006) Adult neurogenesis and functional 
plasticity in neuronal circuits. Nat Rev Neurosci 7:179-193. CrossRef Medline

Lui JH, Nowakowski TJ, Pollen AA, Javaherian A, Kriegstein AR, Oldham MC (2014) Radial glia require PDGFD-PDGFR $\beta$ signalling in human but not mouse neocortex. Nature 515:264-268. CrossRef Medline

Maiuri MC, Zalckvar E, Kimchi A, Kroemer G (2007) Self-eating and selfkilling: crosstalk between autophagy and apoptosis. Nat Rev Mol Cell Biol 8:741-752. CrossRef Medline

Manicklal S, Emery VC, Lazzarotto T, Boppana SB, Gupta RK (2013) The "silent" global burden of congenital cytomegalovirus. Clin Microbiol Rev 26:86-102. CrossRef Medline

McFarlane S, Aitken J, Sutherland JS, Nicholl MJ, Preston VG, Preston CM (2011) Early induction of autophagy in human fibroblasts after infection with human cytomegalovirus or herpes simplex virus 1. J Virol 85:42124221. CrossRef Medline

Monath TP, Cropp CB, Harrison AK (1983) Mode of entry of a neurotropic arbovirus into the central nervous system: reinvestigation of an old controversy. Lab Invest 48:399-410. Medline

Muller WJ, Jones CA, Koelle DM (2010) Immunobiology of herpes simplex virus and cytomegalovirus infections of the fetus and newborn. Curr Immunol Rev 6:38-55. CrossRef Medline

Mutnal MB, Cheeran MC, Hu S, Lokensgard JR (2011) Murine cytomegalovirus infection of neural stem cells alters neurogenesis in the developing brain. PLoS One 6:e16211. CrossRef Medline

Mizushima N, Levine B (2010) Autophagy in mammalian development and differentiation. Nat Cell Biol 12:823-830. CrossRef Medline

Nakatogawa H, Suzuki K, Kamada Y, Ohsumi Y (2009) Dynamics and diversity in autophagy mechanisms: lessons from yeast. Nat Rev Mol Cell Biol 10:458-467. CrossRef Medline

Nguyen Y, Couloigner V, Rudic M, Nguyen Y, Couloigner V, Rudic M, Grayeli AB, Ferrary E, Sterkers O (2009) An animal model of cochlear implantation with an intracochlear fluid delivery system. Acta Otolaryngol 129:1153-1159. CrossRef Medline

Odeberg J, Wolmer N, Falci S, Westgren M, Seiger A, Söderberg-Nauclér C (2006) Human cytomegalovirus inhibits neuronal differentiation and induces apoptosis in human neural precursor cells. J Virol 80:8929-8939. CrossRef Medline

Oliver KR, Scallan MF, Dyson H, Fazakerley JK (1997) Susceptibility to a neurotropic virus and its changing distribution in the developing brain is a function of CNS maturity. J Neurovirol 3:38-48. CrossRef Medline

Park JH, Byeon HK, Park KN, Kim JW, Lee SW, Han KD, Chang JW, Kim WS, Koh YW, Ban MJ (2017) Epidemiological association of olfactory dysfunction with hearing loss and dysphonia in the Korean population: a cross-sectional study. Medicine (Baltimore) 96:e8890. CrossRef Medline

Pereira L, Maidji E (2008) Cytomegalovirus infection in the human placenta: maternal immunity and developmentally regulated receptors on trophoblasts converge. Curr Top Microbiol Immunol 325:383-395. Medline

Philpot BD, Lim JH, Brunjes PC (1997) Activity-dependent regulation of calcium-binding proteins in the developing rat olfactory bulb. J Comp Neurol 387:12-26. CrossRef Medline

Rawlinson WD, Farrell HE, Barrell BG (1996) Analysis of the complete DNA sequence of murine cytomegalovirus. J Virol 70:8833-8849. Medline

Reshef R, Kudryavitskaya E, Shani-Narkiss H, Isaacson B, Rimmerman N, Mizrahi A, Yirmiya R (2017) The role of microglia and their CX3CR1 signaling in adult neurogenesis in the olfactory bulb. Elife 6: e30809. CrossRef Medline

Sakao-Suzuki M, Kawasaki H, Akamatsu T, Meguro S, Miyajima H, Iwashita T, Tsutsui Y, Inoue N, Kosugi I (2014) Aberrant fetal macrophage/microglial reactions to cytomegalovirus infection. Ann Clin Transl Neurol 1:570-588. CrossRef Medline

Sarnat HB (1978) Olfactory reflexes in the newborn infant. J Pediatr 92: 624-626. Medline

Sarnat HB, Yu W (2016) Maturation and dysgenesis of the human olfactory bulb. Brain Pathol 26:301-318. CrossRef Medline

Schaal B, Marlier L, Soussignan R (1998) Olfactory function in the human fetus: evidence from selective neonatal responsiveness to the odor of amniotic fluid. Behav Neurosci 112:1438-1449. CrossRef Medline
Schaal B, Marlier L, Soussignan R (2000) Human foetuses learn odours from their pregnant mother's diet. Chem Senses 25:729-737. CrossRef Medline

Schachtele SJ, Mutnal MB, Schleiss MR, Lokensgard JR (2011) Cytomegalovirus-induced sensorineural hearing loss with persistent cochlear inflammation in neonatal mice. J Neurovirol 17:201-211. CrossRef Medline

Schultz KL, Vernon PS, Griffin DE (2015) Differentiation of neurons restricts arbovirus replication and increases expression of the alpha isoform of IRF-7. J Virol 89:48-60. CrossRef Medline

Scimemi P, Santarelli R, Selmo A, Mammano F (2014) Auditory brainstem responses to clicks and tone bursts in C57BL/6J mice. Acta Otorhinolaryngol Ital 34:264-271. Medline

Semple BD, Blomgren K, Gimlin K, Ferriero DM, Noble-Haeusslein LJ (2013) Brain development in rodents and humans: identifying benchmarks of maturation and vulnerability to injury across species. Prog Neurobiol 106-107:1-16. CrossRef Medline

Seo Y, Kim HS, Kang I, Choi SW, Shin TH, Shin JH, Lee BC, Lee JY, Kim JJ, Kook MG, Kang KS (2016) Cathepsin S contributes to microgliamediated olfactory dysfunction through the regulation of $\mathrm{Cx} 3 \mathrm{cl} 1-\mathrm{Cx} 3 \mathrm{cr} 1$ axis in a Niemann-Pick disease type C1 model. Glia 64:2291-2305. CrossRef Medline

Siopi E, Denizet M, Gabellec MM, de Chaumont F, Olivo-Marin JC, Guilloux JP, Lledo PM, Lazarini F (2016) Anxiety- and depression-like states lead to pronounced olfactory deficits and impaired adult neurogenesis in mice. J Neurosci 36:518-531. CrossRef Medline

Stone DM, Wessel T, Joh TH, Baker H (1990) Decrease in tyrosine hydroxylase, but not aromatic L-amino acid decarboxylase, messenger RNA in rat olfactory bulb following neonatal, unilateral odor deprivation. Brain Res Mol Brain Res 8:291-300. CrossRef Medline

Teissier N, Delezoide AL, Mas AE, Khung-Savatovsky S, Bessières B, Nardelli J, Vauloup-Fellous C, Picone O, Houhou N, Oury JF, Van Den Abbeele T, Gressens P, Adle-Biassette H (2011) Inner ear lesions in congenital cytomegalovirus infection of human fetuses. Acta Neuropathol 122:763774. CrossRef Medline

Teissier N, Fallet-Bianco C, Delezoide AL, Laquerrière A, Marcorelles P, Khung-Savatovsky S, Nardelli J, Cipriani S, Csaba Z, Picone O, Golden JA, Van Den Abbeele T, Gressens P, Adle-Biassette H (2014) Cytomegalovirus-induced brain malformations in fetuses. J Neuropathol Exp Neurol 73:143-158. CrossRef Medline

Tian J, Pinto JM, Cui X, Zhang H, Li L, Liu Y, Wu C, Wei Y (2016) Sendai virus induces persistent olfactory dysfunction in a murine model of PVOD via effects on apoptosis, cell proliferation, and response to odorants. PLoS One 11:e0159033. CrossRef Medline

Townsend CL, Forsgren M, Ahlfors K, Ivarsson SA, Tookey PA, Peckham CS (2013) Long-term outcomes of congenital cytomegalovirus infection in sweden and the united kingdom. Clin Infect Dis 56:1232-1239. CrossRef Medline

Tsutsui Y (2009) Effects of cytomegalovirus infection on embryogenesis and brain development. Congenit Anom (Kyoto) 49:47-55. CrossRef Medline

van Den Pol AN, Mocarski E, Saederup N, Vieira J, Meier TJ (1999) Cytomegalovirus cell tropism, replication, and gene transfer in brain. J Neurosci 19:10948-10965. CrossRef Medline

Watt AP, Loughlin L, Coyle PV (2016) Congenital CMV disease: a female bias in northern Ireland? J Clin Virol 77:99-100. CrossRef Medline

Wheeler DL, Athmer J, Meyerholz DK, Perlman S (2017) Murine olfactory bulb interneurons survive infection with a neurotropic coronavirus. J Virol pii: JVI.01099-17. CrossRef Medline

Whitman MC, Greer CA (2009) Adult neurogenesis and the olfactory system. Prog Neurobiol 89:162-175. CrossRef Medline

Williamson WD, Demmler GJ, Percy AK, Catlin FI (1992) Progressive hearing loss in infants with asymptomatic congenital cytomegalovirus infection. Pediatrics 90:862-866. Medline

Winkler CW, Race B, Phillips K, Peterson KE (2015) Capillaries in the olfactory bulb but not the cortex are highly susceptible to virus-induced vascular leak and promote viral neuroinvasion. Acta Neuropathol 130: 233-245. CrossRef Medline 